Nigerian Journal of Environmental Sciences and Technology (NIJEST)

www.nijest.com

ISSN (Print): 2616-051X ｜ＩSSN (electronic): 2616-0501

Vol 3, No. 1 March 2019, pp 86 - 104

\title{
Climatic Variability and Estimation of Supplementary Irrigation Water Needs of Selected Food Crops in the Sokoto-Rima River Basin, Nigeria
}

\author{
Emeribe C. N. ${ }^{1}{ }^{*}$, Ogbomida E. T. ${ }^{2}$ and Enoma-Calus J. O. ${ }^{3}$ \\ ${ }^{1,2}$ National Centre for Energy and Environment, University of Benin, Benin City, Edo State, Nigeria \\ ${ }^{3}$ Department of Geography, College of Education, Ekiadolor, Benin City, Edo State, Nigeria \\ Corresponding Author: *emeribe.c@ncee.org.ng
}

\begin{abstract}
The study investigated the effects of rainfall and temperature variability on crop water requirements of selected food crops in the Sokoto-Rima River Basin, Northwest of Nigeria. Rainfall and temperature datasets were obtained from the Climatic Research Unit (CRU) TS 3.21 of the University of East Anglia, Norwich, for a period of 70 years (1943-2012). The suitability of CRU datasets were verified by correlating the datasets with measured rainfall data of Yelwa synoptic station, from the Nigerian Meteorological Agency. Selected food crops were used for estimating supplementary irrigation water needs in the River basin. Results of Mann-Kendal, Spearman's Rho and linear regression tests showed strong evidence of increasing annual temperature and potential evapotranspiration with corresponding decrease in rainfall amounts, especially in the northern parts of the basin which houses big irrigation projects and dams such as the Goronyo Irrigation and the Bakolori Dam and Bakolori Irrigation Project. This will impact on the water availability within the basin, through reduction in surface and ground water supply for ongoing irrigation and other water resources projects. Water requirements for selected crops were modeled to ascertain crop sensitivity to climatic variability which will aid in the design of supplementary irrigation water needs models. Results showed that even in the rainfall months, supplementary irrigation of varying quantity is required to complement rainfall, most especially, in the northeast of the basin. Surprisingly, the month of May which marks commencement of rainfall, recorded the highest water need and this has implication for agriculture yields in the region.
\end{abstract}

Keywords: Climatic variability, Supplementary irrigation, Food crops, Rainfall, Temperature

\subsection{Introduction}

The Sokoto-Rima River Basin is located in the Sudano-Sahelian belt of Nigeria, and has a population of more than 15 million (NPC, 2006). Of this population, 75\% depends on rain-fed agriculture for the sustenance of livelihood and food security according to FAO (2018). Climate variability and change has triggered research into the future of water resources and its sustainability under the current situation of climatic uncertainty. Already, it has been reported that the belt is faced with serious environmental challenges arising from aridity in response to climate change, rainfall variability and repeated drought, linked to intensified anthropogenic and natural processes (IPCC, 2007; Bello, 2010; AbdulKadir et al., 2013).

Researchers have also confirmed an increasing rate of desertification in the region (Zhao et al., 2005; Huang and Siegert, 2006; Susana and Kelley, 2006; Sonia et al., 2007; Sivakumar, 2007; Hanafi and Jauffret, 2008). These are threats to agricultural productivity, food security and sustainability of rural livelihood in the region, where subsistent farmers are dominant. Water deficit in the region since the wake of global warming is not expected to improve in the future (Abaje et al., 2011). More importantly, taking into account the population growth and the expected negative effect of climate change on rain pattern in extreme northern Nigeria, the Sokoto-Rima River basin will most likely be faced with the problem of allocating adequate water for agriculture to maintain food security. The major crops involved in food security in the Sokoto-Rima River basin are: wheat, maize, rice, millet, 
beans, guinea corn, tomato, cabbage, carrot, onion. The sensitivity of these crops to climate change has been classified by Allen et al. (1998) as ranging from medium to high in the face of hydrological stress.

Moreover, since agriculture in the basin is essentially rain-fed, changes in climatic variables in particular rainfall and temperature will adversely affect farming operations. For example, Adelana et al. (2003) found that infrequent and short period of rainfall (<60 raining days) in most part of the basin prevent the development of agriculture and restrict crop production in a year to only one planting season per year. This has led to repeated crop failures and declining yields which have led to decrease in the income of farmers and the associated problems of food shortage, malnutrition and general impoverishment of local inhabitants (Ekpoh, 1999; Mortimore and Adams, 2001).

In order to meet the food security of the teaming population of the Sokoto-Rima River Basin, who are mostly subsistent farmers, there is need for scientific quantification of the effect of climate change on crop production. Evapotranspiration, crop factor and water requirements of popularly cultivated crops in the region need to be ascertained. Management of water based on evapotranspiration in river basins has become a developing trend in arid and semi-arid areas (Qin et al., 2009). Evapotranspiration is widely used in guiding agricultural irrigation schedule through the quantitative estimation of the crop water requirement in order to achieve water saving and agricultural yield increase (Dingman, 2002). Previous studies that attempted to examine impacts of climate change on agricultural production in many developing countries concentrated only on general analyses of potential impacts of climate change on crops production, food security and animal husbandry (Odjugo, 2001; Adejuwon, 2006a; Adejuwon, 20076b; Adefolalu, 2007; Jagtap, 2007; Nwafor, 2007). Not much has so far been done in quantifying the effects of climatic variability on crops and on developing supplementary irrigation schedule to guide farmers during long dry spell in rainy season in many developing countries and therefore forms the basis for this study.

\subsection{Materials and Methods}

\subsection{Study area}

The study area is located in Northwestern Nigeria and lies largely in the far North of Sudano- Sahel of West Africa in the zone of Savanna-type vegetation belt generally classified as semi-arid (Sombroek and Zonneveld, 1971). It lies between Latitudes $12^{\circ}$ and $14^{\circ} \mathrm{N}$ and Longitudes $5^{\circ}$ and $7^{\circ} \mathrm{E}$. The basin is underlain by a sequence of inter-bedded semi-consolidated gravels, sands, clays and some limestone and ironstone of cretaceous to quaternary age resting on pre-Cambrain basement complex rocks which outcrop extensively to the east and south of Zamfara State as well as to the south of Kebbi State (Sombroek and Zonneveld, 1971). The Sokoto basin is a semi-arid region marked by distinct weather conditions-the wet and dry seasons. Rainfall is highly seasonal and usually starts from May or June of each year and lasts till September or early October depending on the rainfall pattern for that year. There is a marked seasonal variation in temperature and diurnal range of temperature. Daily maximum temperature of the basin is between $36^{\circ} \mathrm{C}-40^{\circ} \mathrm{C}$. During the harmmattan season, daily minimum temperature may fall below $18^{\circ} \mathrm{C}$. Between February and April which is the peak of heat, temperature reaches the highest of $44^{\circ} \mathrm{C}$. In the extreme north, the shrubby and thorny vegetation of the Sahel zone is the dominant vegetation type.

\subsection{Data collection and analysis}

Precipitation and temperature datasets available on high-resolution $(0.5 \times 0.5$ degree $)$ grids from the Climatic Research Unit (CRU) TS 3.21 of the University of East Anglia, Norwich, United Kingdom (New et al., 2000; Mitchell and Jones, 2005) were used in this study and is available at http://www.cru.uea.ac.uk/. Data were collected for a period of 70 years for Bunza and Dakingari, Southwest of the basin, Gulma and Augi, North West, Goronyo and Galadi, North East and Maje and Dan-Dume South East for the period 1943-2012. Quality control of CRU datasets has been discussed in detail in New et al. (2000). In addition, the suitability of CRU datasets were verified by correlating the rainfall data from this source with measured rainfall data from Yelwa synoptic station, Nigerian Meteorological Agency, for the period 1950-2012. Only points from the CRU dataset that yielded positive relation with NIMET point-gauged data were used in the study (Tables 1 and 2). 


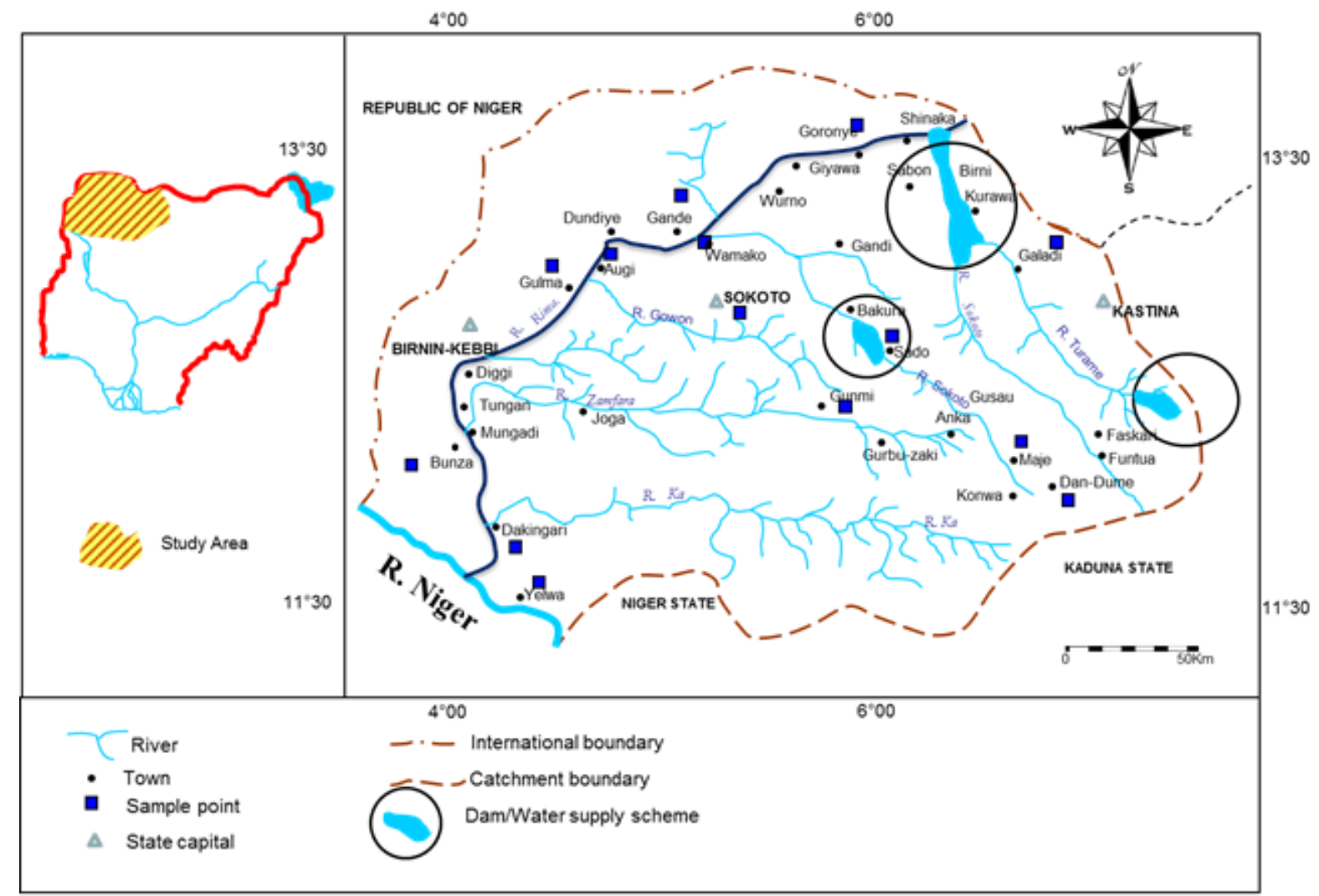

Figure 1: Sokoto River basin

(Source: Adopted from Ita, 1993)

Table 1: Result of correlation of rainfall data from CRU data set with measured data from NIMET (Yelwa Station)

\begin{tabular}{|c|c|c|c|c|}
\hline Data Point & Multiple R & R Square & Adjusted R Square & Standard Error \\
\hline Bunza & 0.97 & 0.94 & 0.93 & 14.8 \\
\hline Dakingari & 0.96 & 0.92 & 0.91 & 17.2 \\
\hline Gulma & 0.97 & 0.95 & 0.95 & 13.5 \\
\hline Augi & 0.98 & 0.96 & 0.96 & 12.1 \\
\hline Goronyo & 0.95 & 0.90 & 0.89 & 29.7 \\
\hline Galadi & 0.96 & 0.92 & 0.92 & 26.1 \\
\hline Maje & 0.97 & 0.95 & 0.94 & 16.7 \\
\hline Dan-dume & 0.97 & 0.94 & 0.93 & 18.8 \\
\hline
\end{tabular}

Correlation was performed on monthly basis

Table 2: Result of correlation of temperature $\left({ }^{\circ} \mathrm{C}\right)$ data from CRU data set with measured data from NIMET (Yelwa Station)

\begin{tabular}{|c|c|c|c|c|}
\hline Data Point & Multiple R & R Square & Adjusted R Square & Standard Error \\
\hline Bunza & 0.96 & 0.92 & 0.91 & 0.6 \\
\hline Dakingari & 0.98 & 0.96 & 0.96 & 0.42 \\
\hline Gulma & 0.93 & 0.87 & 0.85 & 0.83 \\
\hline Augi & 0.92 & 0.86 & 0.85 & 0.8 \\
\hline Goronye & 0.82 & 0.67 & 0.64 & 1.32 \\
\hline Galadi & 0.86 & 0.74 & 0.72 & 1.17 \\
\hline Maje & 0.97 & 0.95 & 0.94 & 0.50 \\
\hline Dan-dume & 0.88 & 0.77 & 0.75 & 1.66 \\
\hline
\end{tabular}

Correlation was performed on monthly basis

\subsection{Data analysis}

Analysis of data was achieved using the excel analysis toolPak. The Thornthwaite water balance computer software version 1.10, developed by the United States Geological Survey Department was used for computing the components of water balance. The choice of this model is based on the nature of physical processes that interact to produce the phenomena under investigation (i.e. temperature rainfall relationship), availability of the required model components/data and wide applicability of the model for hydrological impact of climate change assessment. Although studies have shown, the 
Penman (1948) equation is considered to be the most accurate and has widespread application (Ayoade, 1983; Anyadike, 1987), unfortunately, the model requires a lot of input data which are not readily available in most developing countries for example where net radiation data and soil heat flux. Monthly potential evapotranspiration (PET) was estimated from mean monthly temperature $(T)$. In this study, PET was calculated using the Hamon equation (Hamon, 1961) shown in Equation 1.

$$
P E T_{\text {Hamon }}=13.97 \times d \times D_{2} \times W_{t}
$$

where:

$$
P E T_{\text {Hamon }} \quad P E T \text { in millimeters per month, }
$$

$d \quad$ Number of days in a month,

$\mathrm{D}_{2} \quad$ Mean monthly hours of daylight in units of $12 \mathrm{hrs}$, and

$W_{t} \quad$ Saturated water vapor density term, in grams per cubic meter, calculated using Equation 2:

$W_{t}=\frac{4.95 \times e^{0.062 \times T}}{100}$

where:

$T \quad$ Mean monthly temperature in degrees Celsius (Hamon, 1961)

\subsection{Estimating monthly supplementary irrigation water for selected food crops}

Monthly supplementary irrigation water need of selected crops was calculated by subtracting the effective rainfall from the crop water need. The crop water need is expressed in mm water layer per time unit, in this case $\mathrm{mm} / \mathrm{month}$. If the rainfall is sufficient to provide the water needs of the crops, irrigation is not required. To ascertain if monthly supplementary irrigation is required for any of the selected crops within the Sokoto-Rima River Basin, the model designed by Allen et al. (1998) for estimating supplementary irrigation need was used. The equation is given by:

$I R=E T_{\text {crop }}-P_{e}$ mm month -1

where:

IR Supplementary irrigation in $\mathrm{mm}$;

$E T_{\text {crop }} \quad$ Consumptive water need (mm); and

$P_{e} \quad$ Effective rainfall $(\mathrm{mm})$

$E T_{\text {crop }}$ is defined as the depth (or amount) of water needed to meet the water loss through evapotranspiration. In other words, it is the amount of water needed by the various crops to grow optimally. It is determined as:

$E T_{\text {crop }}=E T_{0} \times K_{c}$

where:

$E T_{o}$

Reference crop evapotranspiration $\left(\mathrm{mm} \mathrm{d}^{-1}\right)$ and also represents an index of climatic demand,

$K_{c} \quad$ Varies predominately with the specific crop characteristics and only to a limited extent with climate.

This relationship enables the transfer of standard values for $K_{c}$ between locations and between climates. This has been a primary reason for the global acceptance and usefulness of the crop coefficient approach and the $K_{c}$ factors developed in past studies (FAO, 1986). Values of $E T_{o}$ were determined using the modified Thornthwaite model (McCabe and Markstrom, 2007).

The $K_{c}$ is a dimensionless crop coefficient. It is the ratio of the crop $E T_{c}$ to the reference $E T_{o}$, and represents an integration of the effects of four primary characteristics that distinguish the crop from reference grass. These are crop height, albedo, canopy resistance and evaporation from soil, especially exposed soil (Allen et al., 1994). Because of the sparseness of data on crop coefficient in 
developing countries, empirical estimates are usually employed and the most common is the FAO estimates (FAO, 1986) (Table 3). The $K_{c}$ values are estimated under a standard climatic condition. This condition has been defined as crops grown in large fields under non-limiting agronomic and soil water conditions (FAO, 2002).

Table 3: Estimated values of crop factor $\left(\mathrm{K}_{\mathrm{c}}\right)$ for various crops under a standard climatic condition and growth stages

\begin{tabular}{|l|l|l|l|l|l|}
\hline Crop & $\begin{array}{l}\text { Total growing } \\
\text { period (days) }\end{array}$ & $\begin{array}{l}\text { Initial stage } \\
K_{c}\end{array}$ & $\begin{array}{l}\text { Crop dev. Stage } \\
K_{c}\end{array}$ & $\begin{array}{l}\text { Mid-season stage } \\
K_{c}\end{array}$ & $\begin{array}{l}\text { Late season } \\
\text { stage } K_{c}\end{array}$ \\
\hline Maize (grain) & $125-180$ & 0.40 & 0.80 & 1.15 & 0.70 \\
\hline Groundnut & $130-140$ & 0.45 & 0.75 & 1.05 & 0.70 \\
\hline Tomato & $135-180$ & 0.45 & 0.75 & 1.15 & 0.80 \\
\hline Cabbage & $120-140$ & 0.45 & 0.75 & 1.05 & 0.90 \\
\hline Carrot & $100-150$ & 0.45 & 0.75 & 1.05 & 0.90 \\
\hline Green Bean & $75-90$ & 0.35 & 0.70 & 1.10 & 0.30 \\
\hline Onion (dry) & $150-210$ & 0.50 & 0.75 & 1.05 & 0.85 \\
\hline Melon & $120-160$ & 0.45 & 0.75 & 1.00 & 0.75 \\
\hline Millet & $105-140$ & 0.35 & 0.70 & 1.10 & 0.65 \\
\hline Sorghum & $120-130$ & 0.35 & 0.75 & 1.10 & 0.65 \\
\hline Soybean & $135-150$ & 0.35 & 0.75 & 1.10 & 0.60 \\
\hline Cucumber & $105-130$ & 0.45 & 0.70 & 0.90 & 0.75 \\
\hline Pepper & $120-210$ & 0.35 & 0.70 & 1.05 & 0.90 \\
\hline Bean (dry) & $95-110$ & 0.35 & 0.70 & 1.10 & 0.30 \\
\hline Potato & $105-145$ & 0.45 & 0.75 & 1.15 & 0.85 \\
\hline
\end{tabular}

Source: FAO Irrigation and Drainage Paper, No. 24 (1986)

To determine the monthly water requirement per crop, $K_{c}$ values for that crop for various stages of growth were averaged.

\subsection{Trend analysis}

Trend analysis of annual rainfall and temperature distributions were determined using a Trend/change detection software (TREND) version 1.0.2 developed by the Cooperative Research Centre for Catchment Hydrology's (CRCCH) Climate Variability Program, in Australia . The scientific development and testing of the software have been carried out at University of Melbourne and Griffith University (Chiew and Siriwardena 2005). TREND is widely adopted by researchers and considered as robust in detecting trends and changes in climatic time series data (Mu et al., 2007; Ma et al., 2008; Zhang and Lu, 2009).

\subsection{Results and Discussion}

\subsection{Temporal trends in rainfall in the Southwest of the Sokoto-Rima basin}

Annual trend of rainfall, southwest of the Sokoto-Rima River Basin is presented in Figure 2. The first three (3) decades from mid-1940, 1950, and 1960 were generally observed to be wet decades. This rising trend was interrupted by a break at the start of 1970 before another rise above rainfall mean value of $827.3 \mathrm{~mm}$ in 2000 . There was a continuous downward trend in rainfall from 1970. Lowest rainfall was observed in 1973 with annual rainfall of $464.6 \mathrm{~mm}$. Other years of much low rains are $1982(529.2 \mathrm{~mm}), 1987(391.2 \mathrm{~mm})$ and $1987(568.6 \mathrm{~mm})$. Highest rainfall of amount $1096.6 \mathrm{~mm}$ was recorded in 1957. Other years of very high rainfall amounts were 1978 and 1946 with rainfall values of $1090.6 \mathrm{~mm}$ and $1087.2 \mathrm{~mm}$ respectively. An average rainfall of $927.7 \mathrm{~mm}$ was recorded in wet years (36 years in which rainfall was above mean value). In the dry years' episode (34 years), rainfall amounts were below the average $(721.1 \mathrm{~mm})$. Figure 3 shows the annual trend of rainfall, NW of Sokoto-Rima River basin (1943-2012). 


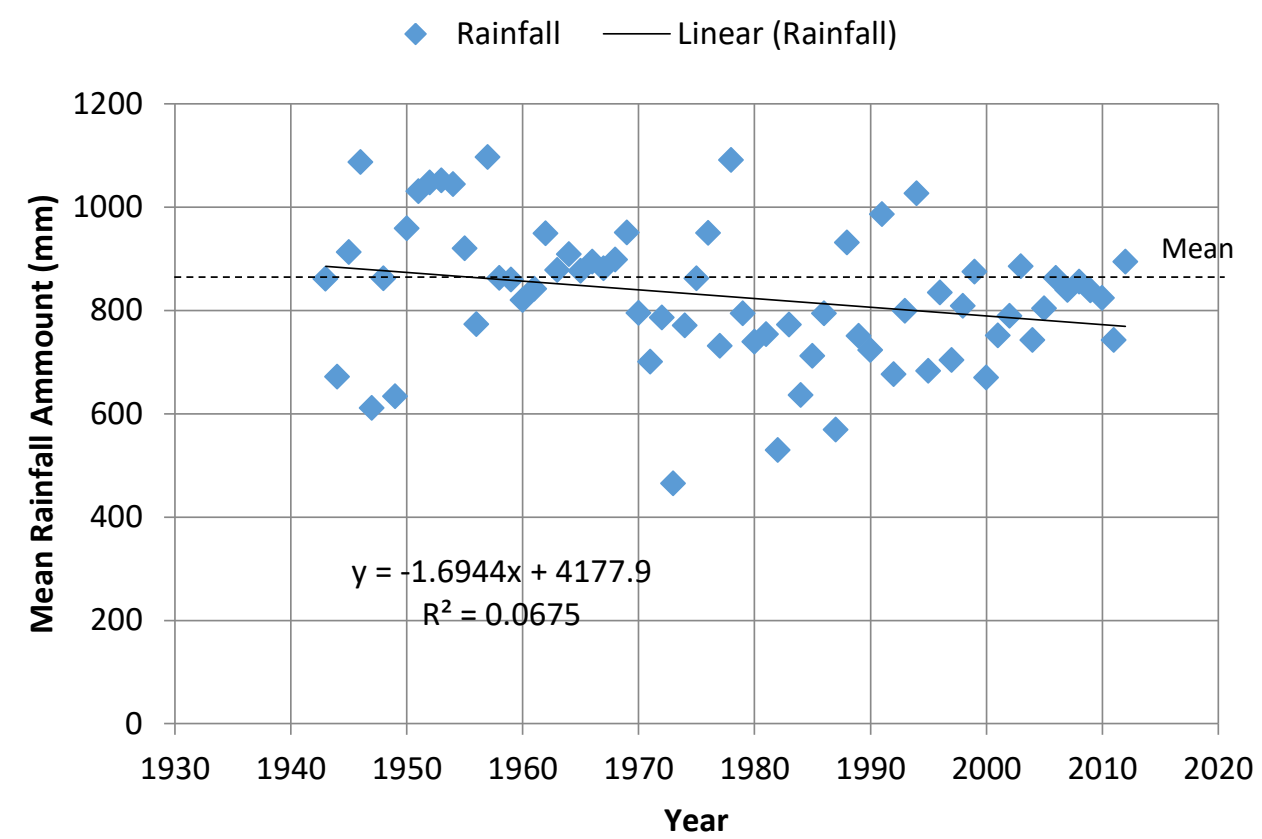

Figure 2: Annual trend of rainfall, SW of Sokoto-Rima River basin (1943-2012)

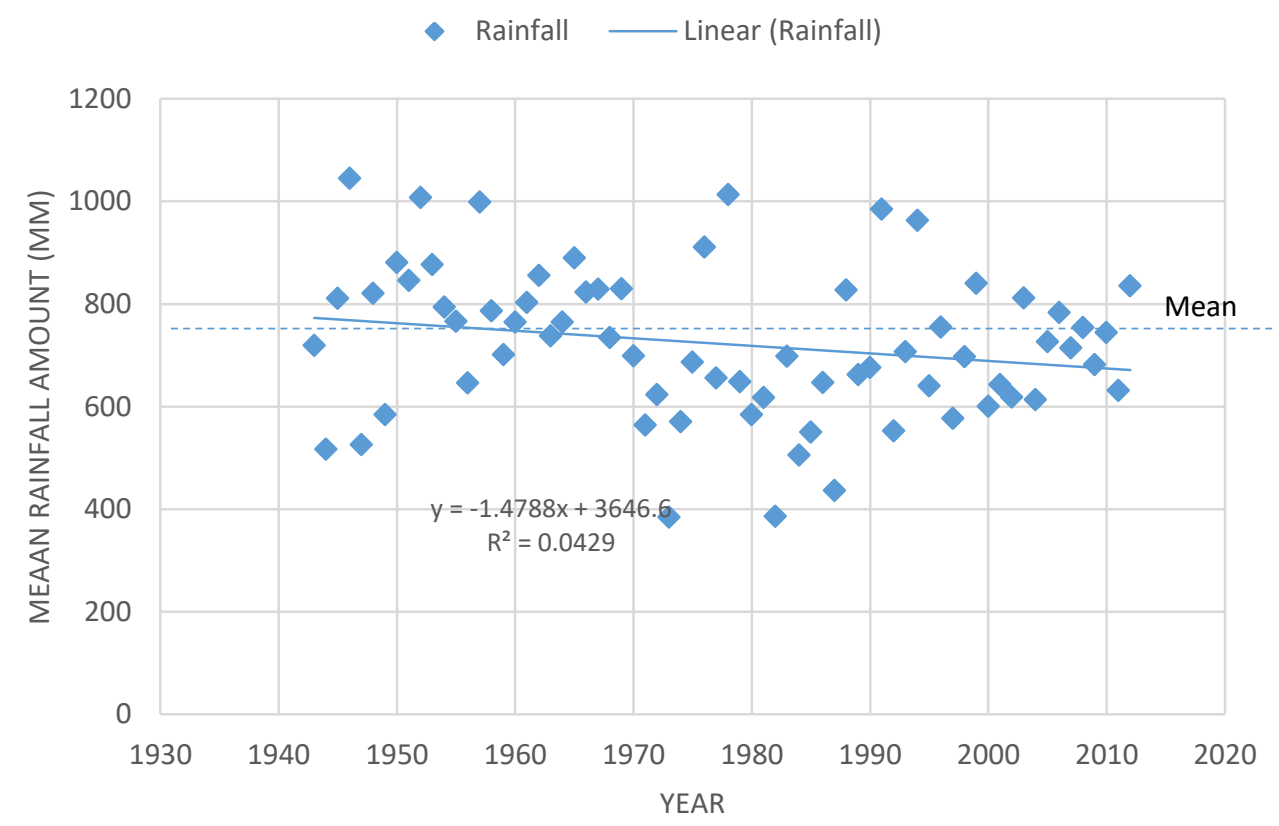

Figure 3: Annual trend of rainfall, NW of Sokoto-Rima River basin (1943-2012)

\subsection{Trend of rainfall, NW of Sokoto-Rima River basin}

In the Northwest of the Sokoto-Rima River basin, wettest years were seen clusterd between 1950, and 1960 as well as part of mid 1940s (Figure 4). This rising trend was interupted by breaks around the start of 1970 when rainfall predominantly decreased below a mean value of $722.3 \mathrm{~mm}$. There was a continous downward trend in rainfall from 1970 which extended into 2000 with very weak sign of recovery in 2010. This is smiliar to the result obtained for China (Junliang et al., 2016). Lowest rain year was 1973 with rainfall amount of $384.4 \mathrm{~mm}$. Other years of significantly low rains were 1982 $(385.8 \mathrm{~mm})$ and $1987(385.8 \mathrm{~mm})$. Maximum rainfall amount of $1044.7 \mathrm{~mm}$ was recorded in 1946. Other years of high rainfall amounts were 1978 and 1952 with rainfall values of $1012.6 \mathrm{~mm}$ and $1007.1 \mathrm{~mm}$ respectively. An average rainfall of $841.3 \mathrm{~mm}$ was recorded in wet years (34) years in which rainfall was above the mean value. In the dry years episode (36 years), rainfall amount was as low as $609.9 \mathrm{~mm}$ on the average. These values obtained were found to be higher than those of the upper East region of Ghana as reported in Abdul-Rahaman et al. (2016). 


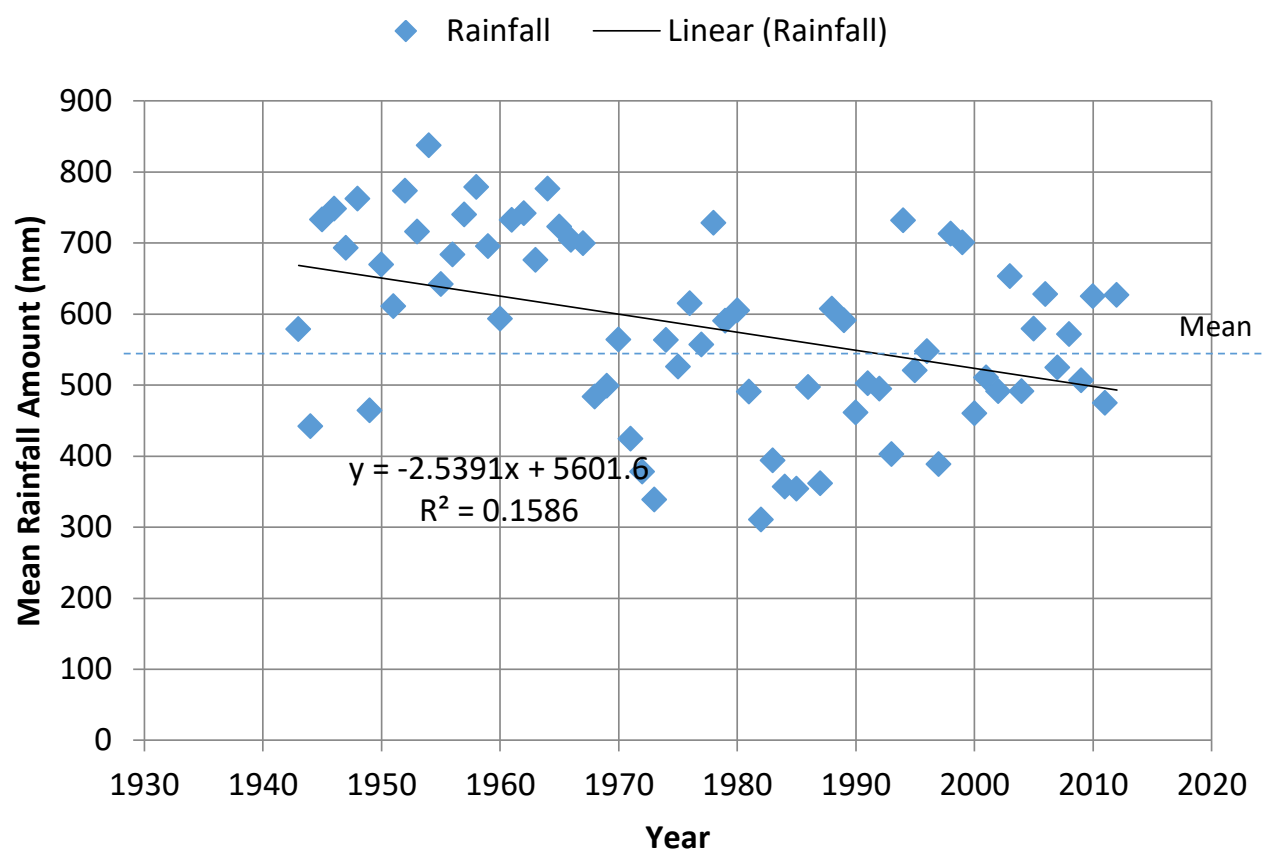

Figure 4: Annual trend of rainfall, NE of Sokoto-Rima River basin (1943-2012)

\subsection{Trend of rainfall, NE of Sokoto-Rima River basin}

In the Northeast of the basin, rainfall pattern varied widely as shown Figure 5. Wet rainfall episode was observed to cluster around mid-1940s, 1950s and 1960s. From 1970s, there was however, a downward trend below the mean value of $580.5 \mathrm{~mm}$ which continued into 2010 with an occasional few years in which rainfall was above the mean value. The lowest rainfall in the Northeast of the basin was observed in 1982 with annual rainfall of $310.6 \mathrm{~mm}$. Other years of very low rains were $1973(338.3 \mathrm{~mm})$ and $1985(353.6 \mathrm{~mm})$. Highest rainfall of amount $837 \mathrm{~mm}$ was recorded in 1954 . An average rainfall of $689.6 \mathrm{~mm}$ was recorded in wet years (35 years in which rainfall was above mean value of $580.5 \mathrm{~mm}$ ). In the dry years' episodes (35 years) in which rainfall amounts were low, the average rainfall amount was $471.5 \mathrm{~mm}$.

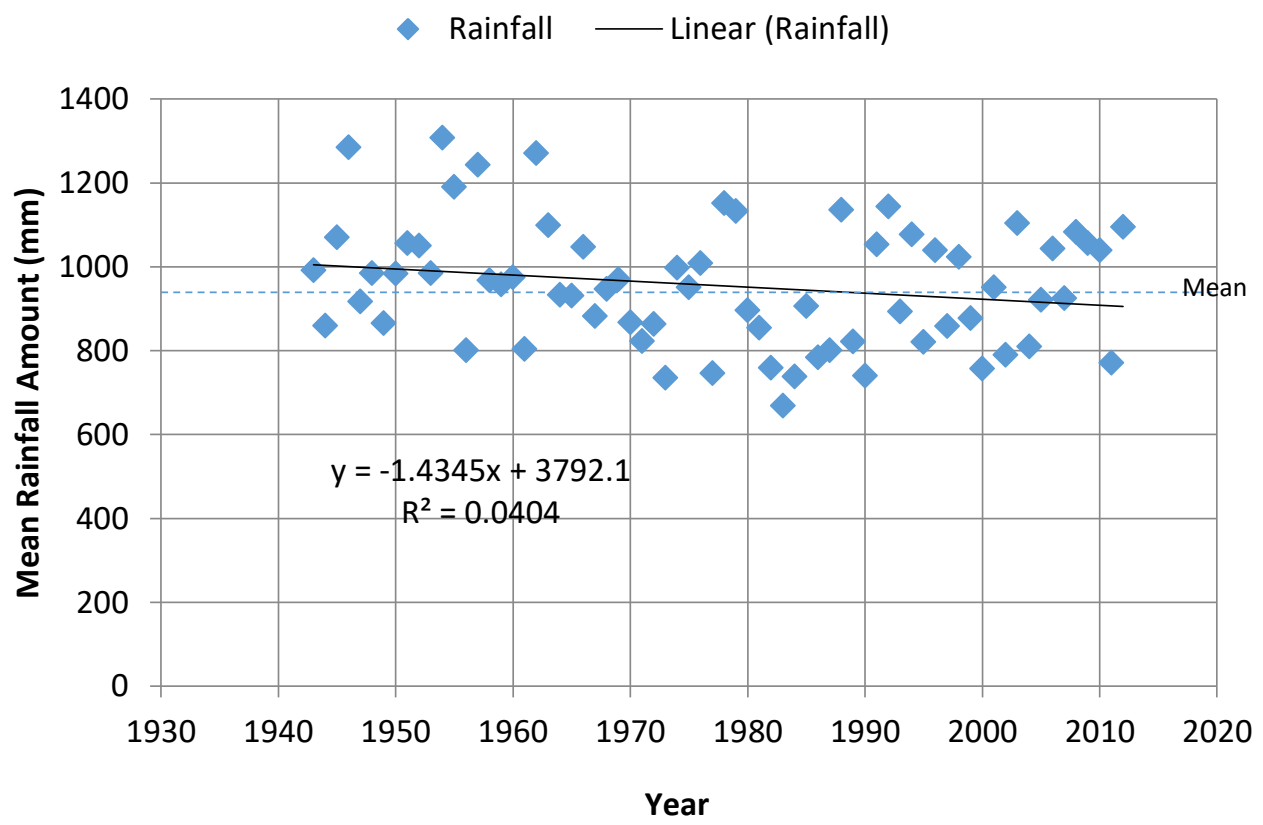

Figure 5: Annual trend of rainfall, SE of Sokoto-Rima River basin (1943-2012) 


\subsection{Trend of rainfall, SE of Sokoto-Rima River basin (1943-2012)}

Unlike the patterns observed in some parts of the basin, there was a gradual decrease in the rainfall amount in the Southeast of the basin. The wettest years were however around 1940s, 1950s, 1960s and part of 1970s before an interrruption in the start of 1980. In 1990 and 2010, there was evidence of recovery though rainfall distribution varied around mean value of $955.3 \mathrm{~mm}$ (Figure 5). Lowest rain year was 1983 with rainfall amount of $668.8 \mathrm{~mm}$. Other years of very low rains were 1973 (734.9 $\mathrm{mm})$ and $1990(740.1 \mathrm{~mm})$. Highest rainfall of amount $1307 \mathrm{~mm}$ was recorded in 1954. Other years of very high rainfall amounts were 1946 and 1962 with rainfall values of $1284.6 \mathrm{~mm}$ and $1270.6 \mathrm{~mm}$ respectively. An average rainfall of $1076.7 \mathrm{~mm}$ was recorded in wet years (34 years in which rainfall was above mean value of $955.3 \mathrm{~mm}$ ). In the dry years episode (36 years) in which rainfall amounts were below average, the average rainfall amount was $840.7 \mathrm{~mm}$.

From Figures 2-5 trends in annual rainfall distribution over Sokoto Rima River basin is best described as experiencing moderate downward trend across 1940-2012. However, for locations in the extreme north of the basin declining annual rainfall amounts seem to be more pronounced when compared to distributions in the southern part of the basin. This is expected as rainfall amount in Nigeria decreases from the coastal south (south of the moisture that produces rain) to the north due to effect of continentality. Similarly, the decrease in rainfall amount for most locations in northwest and northeast of the study area may also be due to increased distance from the zone of influence of topography and the orography as well as in accordance with the general trend in rainfall distribution in Nigeria (Oguntunde et al., 2011). Declining rainfall amount is an important limiting factor for rain-fed crop production. The observed decreasing rainfall amount in the extreme northern parts of the basin will exercerbate the ongoing impacts of climate change and variability, with serious implications for sustainable socio-economic lives, including decline in agricultural activities, drought, migration, health problems, farmer-herdmen crises. Also, pests attack and development of crop diseases, witting and desiccation of crops have been linked to reducing annual rainfall amount (Thompson and Amos, 2010; Obi, 2010; Aondoakaa, 2012; Singh et al., 2014). For example, Obi (2010) reported evidence of reducing pesticide sensitivity due to decreasing precipitation. His study added that pest population may increase across the northern Nigeria and threaten food production. NEMA (2010) has reported the outbreak of pests and diseases due to meteorological drought condition in part of Borno State. Pests and diseases reduce crop yield, quality and value. Since the basin houses big irrigation projects and dams such as the Goronyo Irrigation and the Bakolori Dam and Bakolori Irrigation Project, north of the basin, the observed decrease in annual rainfall trend with corresponding increase in temperature will impact on the water availability of the basin, through reduction in surface and ground water supply for ongoing irrigation and other water resources projects as a result of rapid moisure loss by evaporation and evapotranspiration.

\subsection{Temperature trend in the Southwestern part of Sokoto-Rima River basin}

In Figure 6, temperature varied widely around mean value of $28.7^{\circ} \mathrm{C}$ in the southwestern part of the Sokoto-Rima River basin. Temperature was generally below mean value from 1940 to 1970s. This was however interupted from 1980 and most parts of 2000 and 2010 when there were more years of higher temperature value than the mean. There was a general rising trend in temperature was observed. Lowest temperature was obtained in 1961 with value of $27.7^{\circ} \mathrm{C}$. Other years of very low temperature were $1971\left(27.8^{\circ} \mathrm{C}\right), 1965\left(27.9^{\circ} \mathrm{C}\right)$ and $1975\left(27.9^{\circ} \mathrm{C}\right)$. Highest temperature of $29.8^{\circ} \mathrm{C}$ was recorded in 2009 , followed by 2011 and 1973 with temperature values of $29.6^{\circ} \mathrm{C}$. Northwest of the basin, there was more cluster of temperature below mean value of $28.8^{\circ} \mathrm{C}$ (Figure 6). Temperature was generally below mean value from 1940 to 1970 s with very few years in which temperature was above the mean. From 1980 down to 2010, temperature varied remarkable around the mean line, although there was a cluster of tempeture above mean line in 1980. Lowest temperature was observed in 1961 with temperature value of $27.8^{\circ} \mathrm{C}$. Other years with very low temperature were $1965\left(27.9^{\circ} \mathrm{C}\right)$ and $1975\left(27.1^{\circ} \mathrm{C}\right)$. Highest temperature of $29.9^{\circ} \mathrm{C}$ was recorded in 2009 , followed by 2010 with value of $29.8^{\circ} \mathrm{C}$. 


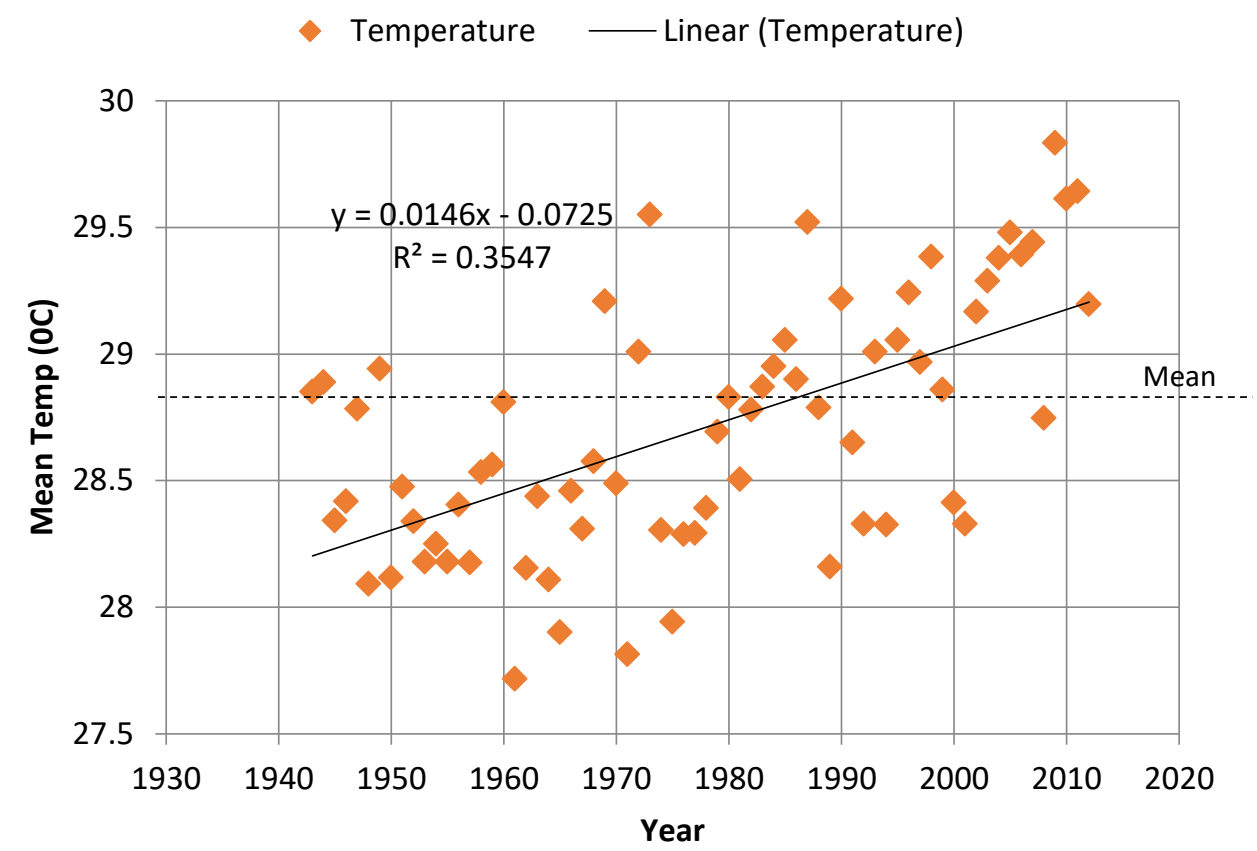

Figure 6: Annual trend of temperature, SW of Sokoto-Rima River basin (1943-2012)

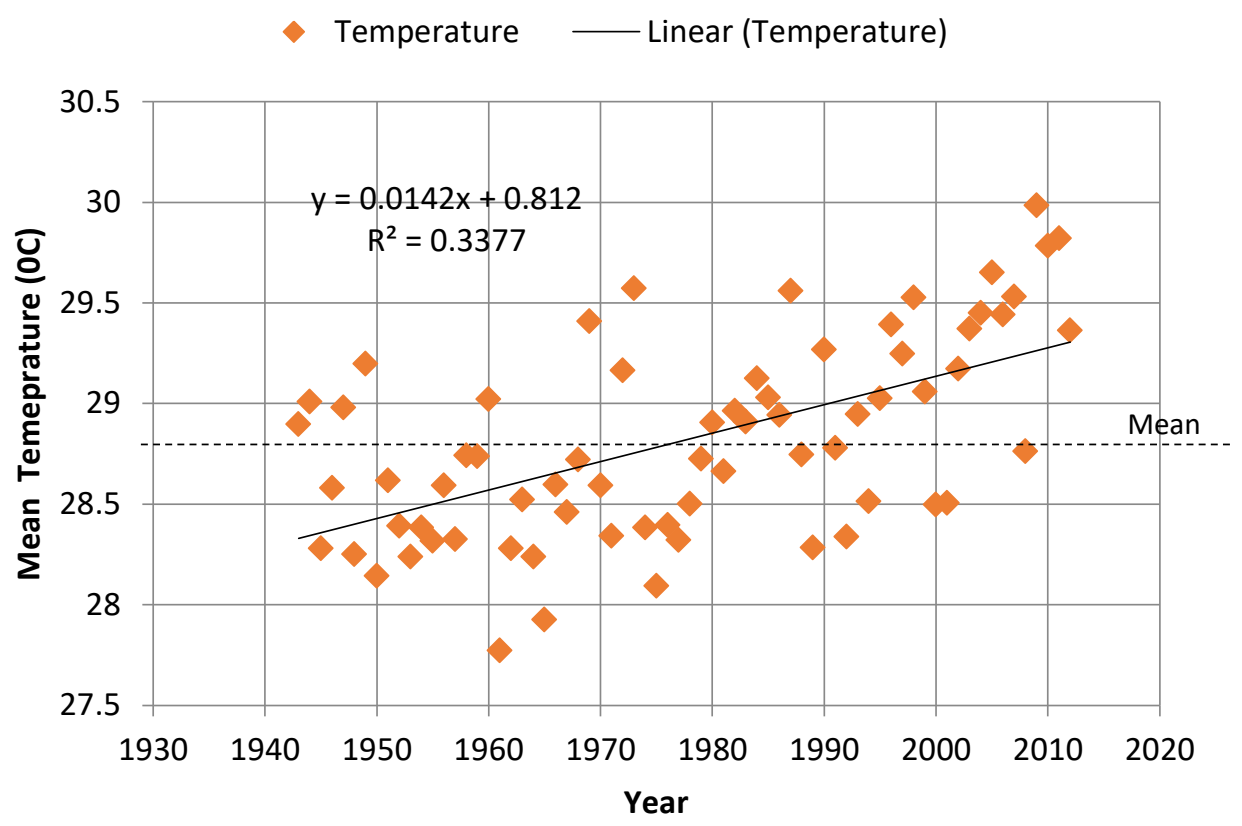

Figure 7: Annual trend of temperature, NW of Sokoto-Rima River basin (1943-2012)

\subsection{Temperature trend in the Northwest and Northeast}

In Figure 8, the annual pattern of temperature in the northeastern part of the Sokoto-Rima River basin is presented. Temperature was generally above mean value of $28.3^{\circ} \mathrm{C}$ from mid-1940 to the $1970 \mathrm{~s}$. This was however interupted from 1980 and most parts of 2000 and 2010 when there were more years in which temperature values were above the mean. A gradual rising trend in temperature was however observed. Lowest temperature was observed in 1961 with temperature value of $27^{\circ} \mathrm{C}$. Other years of very low temperature were $1963\left(27.01^{\circ} \mathrm{C}\right)$ and $1977\left(27.5^{\circ} \mathrm{C}\right)$. Highest temperature of $29.4^{\circ} \mathrm{C}$ was recorded in 1943. 


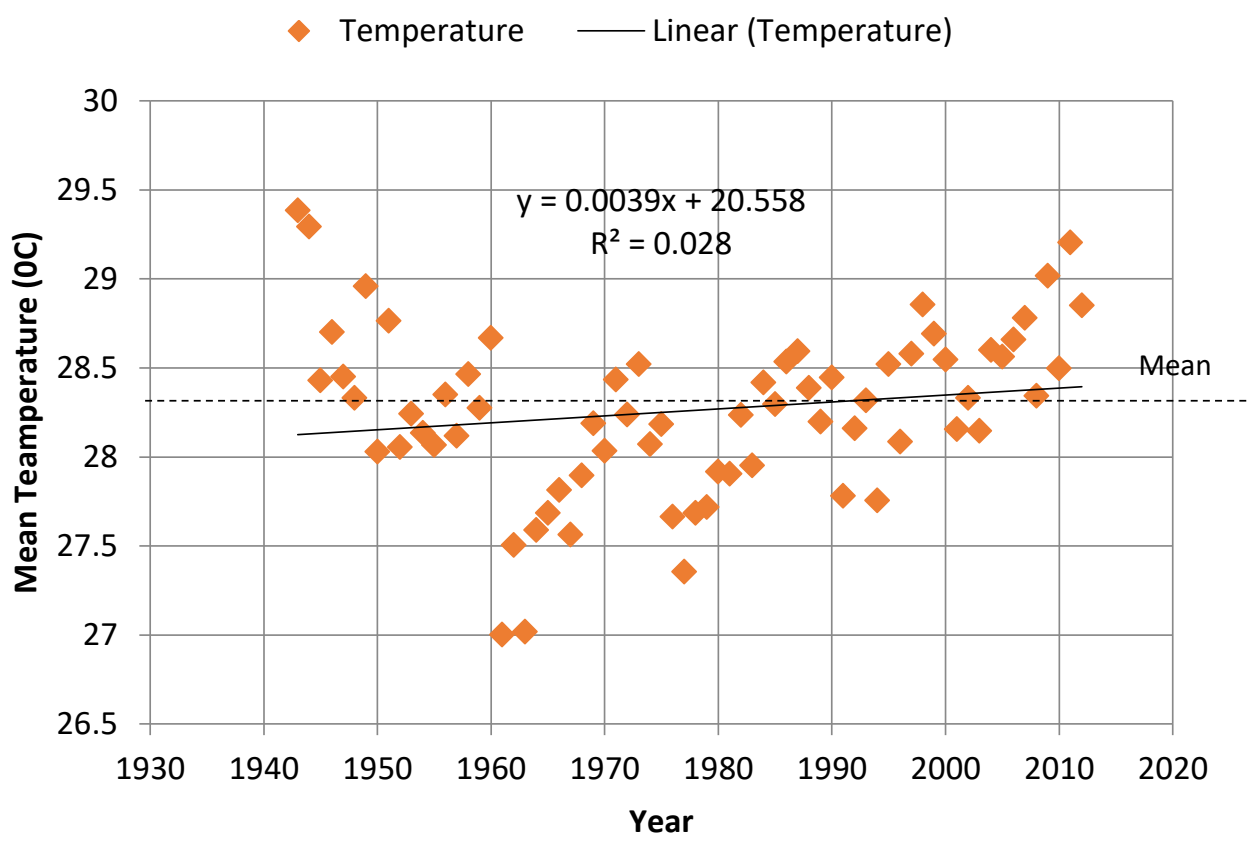

Figure 8: Annual trend of temperature, NE of Sokoto-Rima River basin (1943-2012)

In the Southeast of the basin, there was more cluster of temperature below the mean value of $26.2^{\circ} \mathrm{C}$ (Figure 8). Temperature was generally below mean value from the start of 1950 which extended into 1970. In 1980, however, temperature pattern assumed a rising patttern down to 2010. There were however few years in between, which temperature values were above the mean line. Lowest temperature was observed in 1961 with value of $25.2^{\circ} \mathrm{C}$. Other years with very low temperature were $1989\left(25.5^{\circ} \mathrm{C}\right)$ and $1975\left(25.6^{\circ} \mathrm{C}\right)$. Highest temperature of $27.1^{\circ} \mathrm{C}$ was recorded in 2009 , followed by 2010 with value of $27.0^{\circ} \mathrm{C}$. Figure 9 shows the annual trend of temperature, SE of Sokoto-Rima River basin (1943-2012).

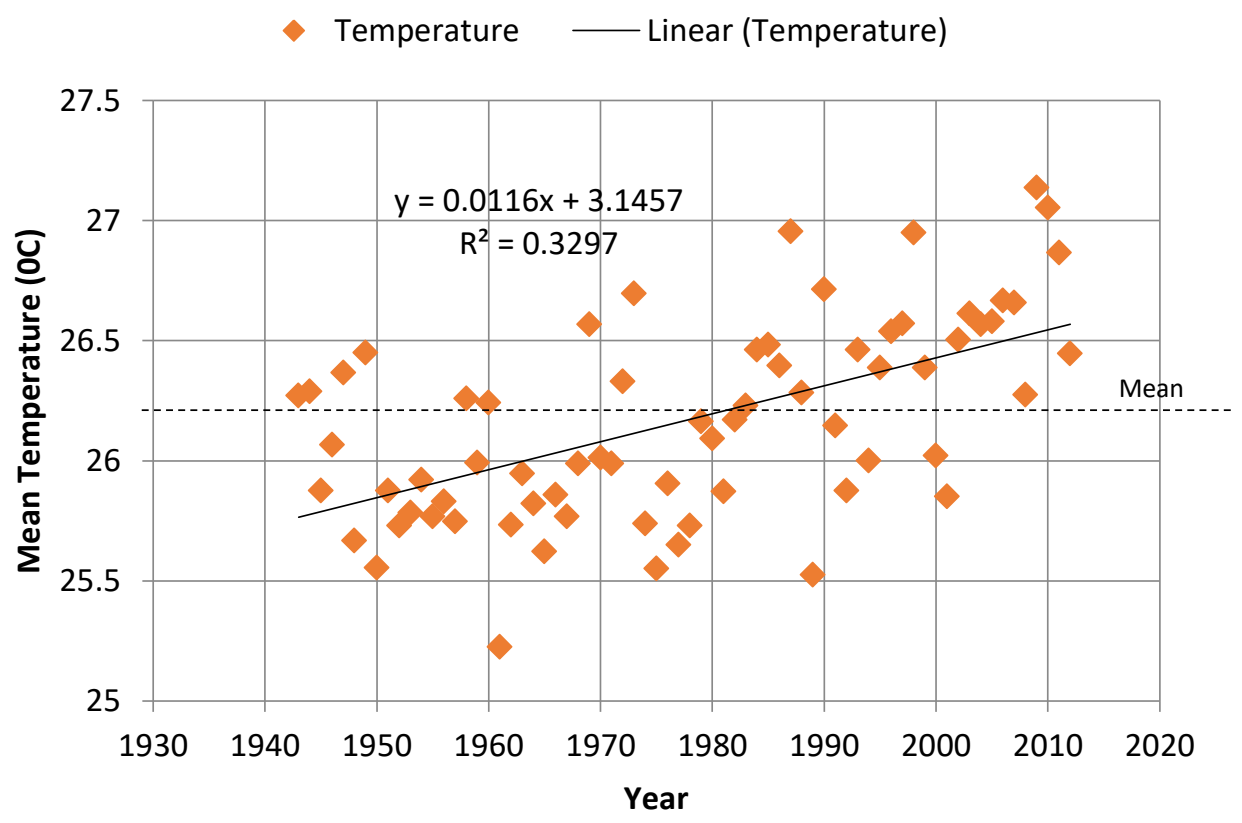

Figure 9: Annual trend of temperature, SE of Sokoto-Rima River basin (1943-2012)

Upward trends in the annual temperature tend to be more pronounced unlike rainfall pattern even though the values coefficients of determination ranges from 0.3-0.45. Rising temperature has been implicated as a direct consequences of global warming. If the present trends in the emission of GHGs through anthropogenic activities continues there is high probability of sharp rise in temperature with 
corresponding decline in rainfall amounts in the region. The observed trends may also point to the fact that uncertainty in climatic variables is a major environmental concern in the basin as there are evidence of rainfall recovery in between extreme or near-extreme climate drought condition. Steady rise in annual temperature pattern has been linked to climate change (IPCC, 2007; Bello, 2010). Thus, the rising annual temperature trend across the basin as shown in this study is an indication of changing climate while the rapid fluctuation around mean value for some locations, south of the basin is an indication of unstable temperature condition. Both climate change and unstable climatic conditions have negative implications for social and economic development within the basin as both phenonemon have the tendency to trigger hydo-meteorological droughts. As temperature rises, crops will loss water rapidly through transpiration thereby increasing crop water need. High potential evapotranspiration (PET) is usually observed during high temperature conditon (Audu et al., 2013). Thus, higher value of PET, means increased moisture loss, leading to deficit water balance which is unfavourable to crops. When plant water deficit is not met on time, it causes contingent drought. Crops growing under low soil moisture, yield little and poor quality seeds. As reported by Obi (2010), while increase in temperature is expected to elongate the growing season in temperate regions, such increase within the tropics is expected to decimate agricultural output by aggravating soil evaporation rate and invariably drought. Ayoade (1983) has also observed that excessive heat destroys the plant protoplasm and also decreases the reproductive capacities of animals. Increasing temperature weakens plants and their leaves wither easily hence poor photosynthesis (Audu et al., 2013). Other studies have established that rising temperure will result in reduced crop quantity and quality due to the reduced growth period following high levels of temperature rise; reduced sugar content, bad coloration, and reduced storage stability in fruits; increase of weeds, blights, and harmful insects in agricultural crops; reduced land fertility due to the accelerated decomposition of organic substances (Kim, 2009). Apart from crops, animals also die in large number during prolonged drought as a result of heat stress, dehydration and attack by drought induced diseases.

\subsection{Temporal trend of climatic variables over the Sokoto-Rima River basin}

Table 4 shows statistical trend patterns of climatic variables over the Sokoto -Rima River basin. Rainfall in SW of the Sokoto-Rima River basin showed evidence of decreasing rainfall. Trend results of rainfall were -2.12 (Mann-Kendall), -2.19 (Spearman's Rho) and -2.18 (linear regression). Trend was detected in rainfall time series at $\alpha<0.05$. Temperature pattern showed evidence of increasing trends for the entire basin. Results of temperature trend were 5.14 (Mann-Kendall), 4.85 (Spearman's Rho) and 6.15 (linear regression). Trend in time series of temperature distribution was detected at $\alpha<$ 0.01. Potential evapotranspiration showed evidence of increasing trend with results of 5.46 (MannKendall), 5.18 (Spearman's Rho) and 6.69 (linear regression) at $\alpha<0.01$.

Northwest of the Sokoto-Rima River basin downward trend results of rainfall was -1.98 (MannKendall), -1.954 (Spearman's Rho) and -2.03 (linear regression) at $\alpha<0.05$ for all the three tests. Temperature showed evidence of increasing trend in the following order; 4.94 (Mann-Kendall), 4.65 (Spearman's Rho) and 5.71 (linear regression). Downward trend in time series of temperature distribution was detected at $\alpha<0.01$ for all the three tests. Potential evapotranspiration showed evidence of increasing trend with trend results of 5.56 (Mann-Kendall), 5.16 (Spearman's Rho) and 6.55 (linear regression) at $\alpha<0.01$.

Rainfall in the north-east of the Sokoto-Rima River basin presented evidence of decreasing trend as follows Mann-Kendall (-3.01), Spearman's Rho (-3.086) and linear regression (-3.56). Temperature pattern showed evidence of increasing trend with the following results; 5.74 (Mann-Kendall), 5.31 (Spearman's Rho) and 6.68 (linear regression). Potential evapotranspiration also showed evidence of increasing trend with trend results of 5.98 (Mann-Kendall), 5.64 (Spearman's Rho) and 7.59 (linear regression). Upward trend was found at $\alpha<0.01$.

Trend results of rainfall southeast of the Sokoto-Rima River basin were -1.78 (Mann-Kendall), -1.81 (Spearman's Rho) and -2.08 (linear regression). Results of Mann-Kendall and spearman's rho present possible evidence of decreasing trend in rainfall pattern. Temperature pattern showed evidence of increasing trend. Results of temperature trend were 4.89 (Mann-Kendall), 4.67 (Spearman's Rho) and 5.83 (linear regression). Potential evapotranspiration distribution showed evidence of increasing trend with trend results of 5.52 (Mann-Kendall), 5.18 (Spearman's Rho) and 6.61 (linear regression). Results of the statistical trends buttressed earlier observations of increasing temperature, PET with 
evidence of declining rainfall. Although changes in annual rainfall distribution are not as pronounced as pattern observed for temperature, the results are indication of changing climate in the basin. In addition to aforementioned direct impacts on crops, there is serious concern in the region concerning desertification. According to Thompson and Amos (2010), desertification is the insidious cause of the decline in Nigeria's agricultural productivity which has taken hold of $35 \%$ of previously cultivable land in eleven (10) northern states. Similarly, Ayuba and Dami (2011) pointed out that Nigeria is losing an estimated land of 351, 000sq.km to desert representing $38 \%$ of its total landmass, which corresponds to the landmass of the desert - threatened frontline states of the country (Bauchi, Gombe, Borno, Yobe, Jigawa, Kano, Katsina, Zamfara, Sokoto and Kebbi States). Regrettably, these states are known for grains (guinea corn, millet, maize, groundnut, beans onions, cucumber etc.) production in the country and now seriously affected by desertification thereby bringing a decline in agricultural produce and causing food insecurity (Audu, et al., 2013). Soils become more loosed and less fertile when encroached by desertification. This threatens farming and affects food production.

Table 4: Trend pattern of climatic variables over the Sokoto-Rima River basin

\begin{tabular}{|c|c|c|c|c|c|c|c|}
\hline $\begin{array}{l}\text { Climatic } \\
\text { station }\end{array}$ & Time series & $\begin{array}{l}\text { Mann- } \\
\text { Kendal }\end{array}$ & \multirow[t]{2}{*}{$\begin{array}{l}\text { Significance } \\
\text { level }\end{array}$} & $\begin{array}{l}\text { Spearman's } \\
\text { Rho }\end{array}$ & \multirow[t]{2}{*}{$\begin{array}{l}\text { Significance } \\
\text { level }\end{array}$} & $\begin{array}{l}\text { Linear } \\
\text { Regression }\end{array}$ & \multirow[t]{2}{*}{$\begin{array}{l}\text { Significance } \\
\text { level }\end{array}$} \\
\hline \multirow{4}{*}{ SW } & $1943-2012$ & z-test & & z-test & & t-test & \\
\hline & Rainfall (mm) & -2.12 & $\alpha<0.05$ & -2.19 & $\alpha<0.05$ & -2.18 & $\alpha<0.05$ \\
\hline & Temp $\left({ }^{0} \mathrm{C}\right)$ & 5.14 & $\alpha<0.01$ & 4.85 & $\alpha<0.01$ & 6.15 & $\alpha<0.01$ \\
\hline & PET(mm) & 5.46 & $\alpha<0.01$ & 5.18 & $\alpha<0.01$ & 6.67 & $\alpha<0.01$ \\
\hline \multirow[t]{3}{*}{ NW } & Rainfall (mm) & -1.98 & $\alpha<0.05$ & -1.954 & $\alpha<0.10$ & -2.03 & $\alpha<0.05$ \\
\hline & Temp $\left({ }^{\circ} \mathrm{C}\right)$ & 4.94 & $\alpha<0.01$ & 4.65 & $\alpha<0.01$ & 5.71 & $\alpha<0.01$ \\
\hline & PET(mm) & 5.56 & $\alpha<0.01$ & 5.16 & $\alpha<0.01$ & 6.55 & $\alpha<0.01$ \\
\hline \multirow[t]{3}{*}{$\mathrm{NE}$} & Rainfall (mm) & -3.01 & $\alpha<0.01$ & -3.086 & $\alpha<0.01$ & -3.56 & $\alpha<0.01$ \\
\hline & Temp $\left({ }^{0} \mathrm{C}\right)$ & 5.74 & $\alpha<0.05$ & 5.31 & $\alpha<0.05$ & 6.68 & $\alpha<0.05$ \\
\hline & PET(mm) & 5.98 & $\alpha<0.01$ & 5.64 & $\alpha<0.01$ & 7.59 & $\alpha<0.01$ \\
\hline \multirow[t]{3}{*}{ SE } & Rainfall (mm) & -1.78 & $\alpha<0.10$ & -1.81 & $\alpha<0.10$ & -2.08 & $\alpha<0.05$ \\
\hline & Temp $\left({ }^{0} \mathrm{C}\right)$ & 4.89 & $\alpha<0.01$ & 4.67 & $\alpha<0.01$ & 5.83 & $\alpha<0.01$ \\
\hline & PET(mm) & 5.52 & $\alpha<0.01$ & 5.18 & $\alpha<0.01$ & 6.61 & $\alpha<0.01$ \\
\hline
\end{tabular}

\subsection{Monthly supplementary irrigation needs of selected crops in the Southwestern part of the basin}

Supplementary irrigation needs of selected crops in the southwestern part of the basin are presented in Tables 5a-5d. Monthly supplementary irrigation needs of maize (grain) was $100.6 \mathrm{~mm}$ in May, 52.9 $\mathrm{mm}$ in June, $-8.4 \mathrm{~mm}$ in July, $-59.8 \mathrm{~mm}$ in August and $-1.6 \mathrm{~mm}$ in September. The negative value of supplementary irrigation need in July, August and September show rainfall is at the peak and maize does not require supplementary irrigation. Similarly, supplementary irrigation is not required for the months of April and October as April rainfall is not considered to be effective enough to commence farming. Thus the month of April a full irrigation may be required. In October which marks the cessation of rainfall in the basin, full irrigation is required. Supplementary irrigation needs for groundnut for the months of May, June, July, August and September were $97.1 \mathrm{~mm}, 49.9 \mathrm{~mm},-11.1$ $\mathrm{mm},-62.1 \mathrm{~mm}$ and $-3.9 \mathrm{~mm}$ respectively. Tomato, cabbage and carrot require supplementary irrigation needs of $105.9 \mathrm{~mm}, 57.4 \mathrm{~mm},-4.3 \mathrm{~mm},-56.1 \mathrm{~mm}$ and $1.9 \mathrm{~mm}$ for the months of May, June, July, August and September respectively. Monthly supplementary irrigation requirement in onion (dry) cultivation were estimated as $100.6 \mathrm{~mm}$ in May, $52.9 \mathrm{~mm}$ in June, $-8.4 \mathrm{~mm}$ in July, $-59.8 \mathrm{~mm}$ in August and $-1.6 \mathrm{~mm}$ in September. Values of supplementary irrigation for selected crops were generally lower in this part of the basin than requirement for maize in North West as well as decrease with increasing rainfall amount.

Table 5a: Monthly supplementary irrigation water need for maize (grain) in $\mathrm{mm}$, southwest, SokotoRima river basin

\begin{tabular}{|l|l|l|l|l|l|l|l|l|l|l|l|l|}
\hline & Jan & Feb & Mar & Apr & May & Jun & Jul & Aug & Sep & Oct & Nov & Dec \\
\hline $\mathrm{ET}_{\mathrm{o}, \mathrm{mm}}$ & 94.1 & 106.8 & 154.1 & 177.4 & 174.5 & 148.6 & 135.0 & 121.4 & 116.4 & 125.1 & 107.0 & 95.1 \\
\hline $\mathrm{K}_{\mathrm{c}}$ & 0.76 & 0.76 & 0.76 & 0.76 & 0.76 & 0.76 & 0.76 & 0.76 & 0.76 & 0.76 & 0.76 & 0.76 \\
\hline $\mathrm{ET}_{\text {crop }}$ & 71.5 & 81.2 & 117.1 & 134.9 & 132.6 & 112.9 & 102.6 & 92.3 & 88.4 & 95.1 & 81.3 & 72.3 \\
\hline $\mathrm{P}_{\mathrm{e}, \mathrm{mm}}$ & 0 & 0 & 0 & 2 & 32 & 60 & 111 & 152 & 90 & 8 & 0 & 0 \\
\hline $\mathrm{IR}, \mathrm{mm}$ & & & & & 100.6 & 52.9 & -8.4 & -59.8 & -1.6 & & & \\
\hline
\end{tabular}

Source: Author's computation, (2017)

Table 5b: Monthly supplementary irrigation water need for groundnut in mm, southwest, SokotoRima river basin

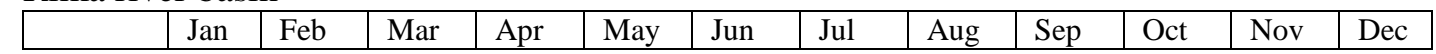




\begin{tabular}{|l|l|l|l|l|l|l|l|l|l|l|l|l|}
\hline $\mathrm{ET}_{\mathrm{i}, \mathrm{mm}}$ & 94.1 & 106.8 & 154.1 & 177.4 & 174.5 & 148.6 & 135.0 & 121.4 & 116.4 & 125.1 & 107.0 & 95.1 \\
\hline $\mathrm{K}_{\mathrm{c}}$ & 0.74 & 0.74 & 0.74 & 0.74 & 0.74 & 0.74 & 0.74 & 0.74 & 0.74 & 0.74 & 0.74 & 0.74 \\
\hline $\mathrm{ET}_{\text {crop }}$ & 69.6 & 79.1 & 114.0 & 131.3 & 129.1 & 109.9 & 99.9 & 89.8 & 86.1 & 92.6 & 79.2 & 70.4 \\
\hline $\mathrm{P}_{\mathrm{e}, \mathrm{mm}}$ & 0 & 0 & 0 & 2 & 32 & 60 & 111 & 152 & 90 & 8 & 0 & 0 \\
\hline $\mathrm{IR}, \mathrm{mm}$ & & & & & 97.1 & 49.9 & -11.1 & -62.2 & -3.9 & & & \\
\hline
\end{tabular}

Source: Author's computation, (2017)

Table 5c: Monthly supplementary irrigation water need for tomato/cabbage/carrot in mm, southwest, Sokoto-Rima river basin

\begin{tabular}{|l|l|l|l|l|l|l|l|l|l|l|l|l|}
\hline & Jan & Feb & Mar & Apr & May & Jun & Jul & Aug & Sep & Oct & Nov & Dec \\
\hline $\mathrm{ET}_{\mathrm{o}, \mathrm{mm}}$ & 94.1 & 106.8 & 154.1 & 177.4 & 174.5 & 148.6 & 135.0 & 121.4 & 116.4 & 125.1 & 107.0 & 95.1 \\
\hline $\mathrm{K}_{\mathrm{c}}$ & 0.79 & 0.79 & 0.79 & 0.79 & 0.79 & 0.79 & 0.79 & 0.79 & 0.79 & 0.79 & 0.79 & 0.79 \\
\hline $\mathrm{ET}_{\text {crop }}$ & 74.3 & 84.4 & 121.7 & 140.2 & 137.9 & 117.4 & 106.7 & 95.9 & 91.9 & 98.8 & 84.5 & 75.2 \\
\hline $\mathrm{P}_{\mathrm{e}, \mathrm{mm}} \mathrm{mm}$ & 0 & 0 & 0 & 2 & 32 & 60 & 111 & 152 & 90 & 8 & 0 & 0 \\
\hline IR, mm & & & & & 105.9 & 57.4 & -4.3 & -56.1 & 1.9 & & & \\
\hline
\end{tabular}

Source: Author's computation, (2017)

Table 5d: Monthly supplementary irrigation water need for onion (dry) in mm, southwest, SokotoRima river basin

\begin{tabular}{|l|l|l|l|l|l|l|l|l|l|l|l|l|}
\hline & Jan & Feb & Mar & Apr & May & Jun & Jul & Aug & Sep & Oct & Nov & Dec \\
\hline $\mathrm{ET}_{\mathrm{o}, \mathrm{mm}}$ & 94.1 & 106.8 & 154.1 & 177.4 & 174.5 & 148.6 & 135.0 & 121.4 & 116.4 & 125.1 & 107.0 & 95.1 \\
\hline $\mathrm{K}_{\mathrm{c}}$ & 0.76 & 0.76 & 0.76 & 0.76 & 0.76 & 0.76 & 0.76 & 0.76 & 0.76 & 0.76 & 0.76 & 0.76 \\
\hline $\mathrm{ET}_{\text {crop }}$ & 71.5 & 81.2 & 117.1 & 134.9 & 132.6 & 112.9 & 102.6 & 92.2 & 88.4 & 95.1 & 81.3 & 72.3 \\
\hline $\mathrm{P}_{\mathrm{e}, \mathrm{mm}}$ & 0 & 0 & 0 & 2 & 32 & 60 & 111 & 152 & 90 & 8 & 0 & 0 \\
\hline $\mathrm{IR}, \mathrm{mm}$ & & & & & 100.6 & 52.9 & -8.4 & -59.8 & -1.6 & 87.1 & & \\
\hline
\end{tabular}

Source: Author's computation, (2017)

\subsection{Monthly supplementary irrigation needs of selected crops in the Northwestern part of the basin}

Tables 6a-6d show the supplementary irrigation needs of selected crops in the Northwestern part of the basin area. Monthly supplementary irrigation needs of maize (grain) was $127.7 \mathrm{~mm}$ in May, 74.4 $\mathrm{mm}$ in June, $11.7 \mathrm{~mm}$ in July, $-32.3 \mathrm{~mm}$ in August and $32.02 \mathrm{~mm}$ in September. Values of supplementary irrigation were observed to decrease with increasing rainfall amount. Highest supplementary irrigation requirement was found in May. This very high value may be attributed to general high temperature value which characterize onset of rainfall in the study area. Supplementary irrigation needs for groundnut cultivation for the months of May, June, July, August and September were $123.9 \mathrm{~mm}, 71.1 \mathrm{~mm}, 8.9 \mathrm{~mm},-34.8 \mathrm{~mm}$ and $29.6 \mathrm{~mm}$ respectively. Tomato, cabbage and carrot require supplementary irrigation needs of $133.3 \mathrm{~mm}, 79.3 \mathrm{~mm}, 15.9 \mathrm{~mm},-28.6 \mathrm{~mm}$ and $35.7 \mathrm{~mm}$ for the months of May, June, July, August and September respectively. Monthly supplementary irrigation requirement in onion (dry) cultivation were estimated as $127.7 \mathrm{~mm}$ in May, $74.4 \mathrm{~mm}$ in June, $11.7 \mathrm{~mm}$ in July, $-32.3 \mathrm{~mm}$ in August and $32.0 \mathrm{~mm}$ in September.

Table 6a: Monthly supplementary irrigation water need for maize (grain) in mm, northwest, SokotoRima river basin

\begin{tabular}{|l|l|l|l|l|l|l|l|l|l|l|l|l|}
\hline & Jan & Feb & Mar & Apr & May & Jun & Jul & Aug & Sep & Oct & Nov & Dec \\
\hline $\mathrm{ET}_{\mathrm{o}, \mathrm{mm}}$ & 88.2 & 101.4 & 148.1 & 178.7 & 186.4 & 159.7 & 140.4 & 124.6 & 121.1 & 130.1 & 106.3 & 90.4 \\
\hline $\mathrm{K}_{\mathrm{c}}$ & 0.76 & 0.76 & 0.76 & 0.76 & 0.76 & 0.76 & 0.76 & 0.76 & 0.76 & 0.76 & 0.76 & 0.76 \\
\hline $\mathrm{ET}_{\text {crop }}$ & 66.9 & 77.04 & 112.5 & 135.8 & 141.7 & 121.5 & 106.7 & 94.6 & 92.0 & 98.8 & 80.8 & 68.7 \\
\hline $\mathrm{P}_{\mathrm{e}, \mathrm{mm}}$ & 0 & 0 & 0 & 0 & 14 & 47 & 95 & 127 & 60 & 2 & 0 & 0 \\
\hline $\mathrm{IR}, \mathrm{mm}$ & & & & & 127.7 & 74.4 & 11.7 & -32.3 & 32.02 & & & \\
\hline
\end{tabular}

Source: Author's computation, (2017)

Table 6b: Monthly supplementary irrigation water need for groundnut in mm, northwest, SokotoRima river basin

\begin{tabular}{|l|l|l|l|l|l|l|l|l|l|l|l|l|}
\hline & Jan & Feb & Mar & Apr & May & Jun & Jul & Aug & Sep & Oct & Nov & Dec \\
\hline $\mathrm{ET}_{\mathrm{o}, \mathrm{mm}}$ & 88.2 & 101.4 & 148.1 & 178.7 & 186.4 & 159.7 & 140.4 & 124.6 & 121.1 & 130.1 & 106.3 & 90.4 \\
\hline $\mathrm{K}_{\mathrm{c}}$ & 0.74 & 0.74 & 0.74 & 0.74 & 0.74 & 0.74 & 0.74 & 0.74 & 0.74 & 0.74 & 0.74 & 0.74 \\
\hline $\mathrm{ET}_{\text {crop }}$ & 65.2 & 75.0 & 109.5 & 132.2 & 137.9 & 118.1 & 103.9 & 92.2 & 89.6 & 96.3 & 78.7 & 66.9 \\
\hline $\mathrm{P}_{\mathrm{e}, \mathrm{mm}}$ & 0 & 0 & 0 & 0 & 14 & 47 & 95 & 127 & 60 & 2 & 0 & 0 \\
\hline $\mathrm{IR}, \mathrm{mm}$ & & & & & 123.9 & 71.1 & 8.9 & -34.8 & 29.6 & & & \\
\hline
\end{tabular}

Source: Author's computation, (2017)

Table 6c: Monthly supplementary irrigation water need for tomato/cabbage/carrot in mm, Northwest, Sokoto-Rima river basin

\begin{tabular}{|l|l|l|l|l|l|l|l|l|l|l|l|l|}
\hline & Jan & Feb & Mar & Apr & May & Jun & Jul & Aug & Sep & Oct & Nov & Dec \\
\hline
\end{tabular}




\begin{tabular}{|l|l|l|l|l|l|l|l|l|l|l|l|l|}
\hline $\mathrm{ET}_{\mathrm{i}, \mathrm{mm}}$ & 88.2 & 101.4 & 148.1 & 178.7 & 186.4 & 159.7 & 140.4 & 124.6 & 121.1 & 130.1 & 106.3 & 90.4 \\
\hline $\mathrm{K}_{\mathrm{c}}$ & 0.79 & 0.79 & 0.79 & 0.79 & 0.79 & 0.79 & 0.79 & 0.79 & 0.79 & 0.79 & 0.79 & 0.79 \\
\hline $\mathrm{ET}_{\mathrm{crop}}$ & 69.6 & 80.1 & 116.9 & 141.2 & 147.3 & 126.1 & 110.9 & 98.40 & 95.65 & 102.7 & 84.01 & 71.4 \\
\hline $\mathrm{P}_{\mathrm{e}, \mathrm{mm}}$ & 0 & 0 & 0 & 0 & 14 & 47 & 95 & 127 & 60 & 2 & 0 & 0 \\
\hline $\mathrm{IR}, \mathrm{mm}$ & & & & & 133.3 & 79.1 & 15.9 & -28.6 & 35.7 & & & \\
\hline
\end{tabular}

Source: Author's computation, (2017)

Table 6d: Monthly supplementary irrigation water need for onion (dry) in mm, northwest, SokotoRima river basin

\begin{tabular}{|l|l|l|l|l|l|l|l|l|l|l|l|l|}
\hline & Jan & Feb & Mar & Apr & May & Jun & Jul & Aug & Sep & Oct & Nov & Dec \\
\hline $\mathrm{ET}_{\mathrm{o}, \mathrm{mm}}$ & 88.2 & 101.4 & 148.1 & 178.7 & 186.4 & 159.7 & 140.4 & 124.6 & 121.1 & 130.1 & 106.3 & 90.4 \\
\hline $\mathrm{K}_{\mathrm{c}}$ & 0.76 & 0.76 & 0.76 & 0.76 & 0.76 & 0.76 & 0.76 & 0.76 & 0.76 & 0.76 & 0.76 & 0.76 \\
\hline $\mathrm{ET}_{\text {crop }}$ & 66.9 & 77.04 & 112.6 & 135.8 & 141.7 & 121.4 & 106.7 & 94.6 & 92.0 & 98.8 & 80.8 & 68.7 \\
\hline $\mathrm{P}_{\mathrm{e}, \mathrm{mm}}$ & 0 & 0 & 0 & 0 & 14 & 47 & 95 & 127 & 60 & 2 & 0 & 0 \\
\hline $\mathrm{IR}, \mathrm{mm}$ & & & & & 127.7 & 74.4 & 11.7 & -32.3 & 32.0 & & & \\
\hline
\end{tabular}

Source: Author's computation, (2017)

\subsection{Supplementary irrigation needs of Selected Crops in Northeastern part of the basin}

Supplementary irrigation needs of selected crops in Northeastern part of the basin area are presented in Tables 7a-7d. Monthly supplementary irrigation needs of maize (grain) was $125.2 \mathrm{~mm}$ in May, $125.2 \mathrm{~mm}$ in June, $7.5 \mathrm{~mm}$ in July, $-37.9 \mathrm{~mm}$ in August and $34.6 \mathrm{~mm}$ in September. The negative value of supplementary irrigation need in August shows rainfall is at peak and maize does not require supplementary irrigation. These values are generally higher than water needs of maize in southwestern part of the basin. Supplementary irrigation needs for groundnut cultivation for the months of May, June, July, August and September were $121.7 \mathrm{~mm}, 72.4 \mathrm{~mm}, 4.8 \mathrm{~mm},-40.4 \mathrm{~mm}$ and $32.2 \mathrm{~mm}$ respectively. These values are generally higher in this part of the basin compared to the requirement for groundnut in southwest. Tomato, cabbage and carrot require supplementary irrigation needs of $130.6 \mathrm{~mm}, 80.2 \mathrm{~mm}, 11.6 \mathrm{~mm},-34.3 \mathrm{~mm}$ and $38.1 \mathrm{~mm}$ for the months of May, June, July, August and September respectively. Monthly supplementary irrigation requirement in onion (dry) cultivation were estimated as $125.2 \mathrm{~mm}$ in May, $75.5 \mathrm{~mm}$ in June, $-7.5 \mathrm{~mm}$ in July, $-37.9 \mathrm{~mm}$ in August and $34.6 \mathrm{~mm}$ in September. These values are generally higher when compared to water requirement for onion in southwest and north-western parts of the basin.

Table 7a: Monthly supplementary irrigation water need for maize (grain) in mm, northeast, SokotoRima river basin

\begin{tabular}{|l|l|l|l|l|l|l|l|l|l|l|l|l|}
\hline & Jan & Feb & Mar & Apr & May & Jun & Jul & Aug & Sep & Oct & Nov & Dec \\
\hline $\mathrm{ET}_{\mathrm{o}, \mathrm{mm}}$ & 81.4 & 92.5 & 136.9 & 168.5 & 177.9 & 154.7 & 134.9 & 121.1 & 117.9 & 123.1 & 99.3 & 83.2 \\
\hline $\mathrm{K}_{\mathrm{c}}$ & 0.76 & 0.76 & 0.76 & 0.76 & 0.76 & 0.76 & 0.76 & 0.76 & 0.76 & 0.76 & 0.76 & 0.76 \\
\hline $\mathrm{ET}_{\text {crop }}$ & 61.9 & 70.3 & 104.1 & 128.0 & 135.2 & 117.5 & 102.5 & 92.0 & 89.6 & 93.5 & 75.5 & 63.2 \\
\hline $\mathrm{P}_{\mathrm{e}, \mathrm{mm}}$ & 0 & 0 & 0 & 0 & 10 & 42 & 95 & 130 & 55 & 2 & 0 & 0 \\
\hline $\mathrm{IR}, \mathrm{mm}$ & & & & & 125.2 & 75.5 & 7.5 & -37.9 & 34.6 & & & \\
\hline
\end{tabular}

Source: Author's computation, (2017)

Table 7b: Monthly supplementary irrigation water need for groundnut in $\mathrm{mm}$, northeast, SokotoRima river basin

\begin{tabular}{|l|l|l|l|l|l|l|l|l|l|l|l|l|}
\hline & Jan & Feb & Mar & Apr & May & Jun & Jul & Aug & Sep & Oct & Nov & Dec \\
\hline $\mathrm{ET}_{\mathrm{o}, \mathrm{mm}}$ & 81.4 & 92.5 & 136.9 & 168.5 & 177.9 & 154.7 & 134.9 & 121.1 & 117.9 & 123.1 & 99.3 & 83.2 \\
\hline $\mathrm{K}_{\mathrm{c}}$ & 0.74 & 0.74 & 0.74 & 0.74 & 0.74 & 0.74 & 0.74 & 0.74 & 0.74 & 0.74 & 0.74 & 0.74 \\
\hline $\mathrm{ET}_{\text {crop }}$ & 60.2 & 68.5 & 101.4 & 124.7 & 131.7 & 114.4 & 99.8 & 89.6 & 87.2 & 91.1 & 73.5 & 61.6 \\
\hline $\mathrm{P}_{\mathrm{e}, \mathrm{mm}}$ & 0 & 0 & 0 & 0 & 10 & 42 & 95 & 130 & 55 & 2 & 0 & 0 \\
\hline $\mathrm{IR}, \mathrm{mm}$ & & & & & 121.7 & 72.4 & 4.8 & -40.4 & 32.2 & & & \\
\hline
\end{tabular}

Source: Author's computation, (2017)

Table 7c: Monthly supplementary irrigation water need for tomato/cabbage/carrot in mm, northeast, Sokoto-Rima river basin

\begin{tabular}{|l|l|l|l|l|l|l|l|l|l|l|l|l|}
\hline & Jan & Feb & Mar & Apr & May & Jun & Jul & Aug & Sep & Oct & Nov & Dec \\
\hline $\mathrm{ET}_{\mathrm{o}, \mathrm{mm}}$ & 81.4 & 92.5 & 136.9 & 168.5 & 177.9 & 154.7 & 134.9 & 121.1 & 117.0 & 123.1 & 99.3 & 83.2 \\
\hline $\mathrm{K}_{\mathrm{c}}$ & 0.79 & 0.79 & 0.79 & 0.79 & 0.79 & 0.79 & 0.79 & 0.79 & 0.79 & 0.79 & 0.79 & 0.79 \\
\hline $\mathrm{ET}_{\text {crop }}$ & 64.3 & 73.1 & 108.2 & 133.1 & 140.6 & 122.2 & 106.6 & 95.7 & 93.1 & 97.2 & 78.5 & 65.7 \\
\hline $\mathrm{P}_{\mathrm{e}, \mathrm{mm}}$ & 0 & 0 & 0 & 0 & 10 & 42 & 95 & 130 & 55 & 2 & 0 & 0 \\
\hline $\mathrm{IR}, \mathrm{mm}$ & & & & & 130.6 & 80.2 & 11.6 & -34.3 & 38.1 & & & \\
\hline
\end{tabular}

Source: Author's computation, (2017) 
Table 7d: Monthly supplementary irrigation water need for onion (dry) in mm, northeast, SokotoRima river basin

\begin{tabular}{|l|l|l|l|l|l|l|l|l|l|l|l|l|}
\hline & Jan & Feb & Mar & Apr & May & Jun & Jul & Aug & Sep & Oct & Nov & Dec \\
\hline $\mathrm{ET}_{\mathrm{o}, \mathrm{mm}}$ & 81.4 & 92.5 & 136.98 & 168.5 & 177.9 & 154.7 & 134.9 & 121.1 & 117.9 & 123.1 & 99.3 & 83.2 \\
\hline $\mathrm{K}_{\mathrm{c}}$ & 0.76 & 0.76 & 0.76 & 0.76 & 0.76 & 0.76 & 0.76 & 0.76 & 0.76 & 0.76 & 0.76 & 0.76 \\
\hline $\mathrm{ET}_{\text {crop }}$ & 61.8 & 70.3 & 104.1 & 128.0 & 135.2 & 117.5 & 102.5 & 92.0 & 89.6 & 93.5 & 75.5 & 63.2 \\
\hline $\mathrm{P}_{\mathrm{e}, \mathrm{mm}}$ & 0 & 0 & 0 & 0 & 10 & 42 & 95 & 130 & 55 & 2 & 0 & 0 \\
\hline $\mathrm{IR}, \mathrm{mm}$ & & & & & 125.2 & 75.5 & 7.5 & -37.9 & 34.6 & & & \\
\hline
\end{tabular}

Source: Author's computation, (2017)

\subsection{Supplementary irrigation needs of selected crops in Southeastern part of the basin}

Supplementary irrigation needs of selected crops in south-eastern part of the basin are presented in Tables 8a-8d. Monthly supplementary irrigation needs of maize (grain) was $81.0 \mathrm{~mm}$ in May, 33.7 $\mathrm{mm}$ in June, $-39.5 \mathrm{~mm}$ in July, $-99.6 \mathrm{~mm}$ in August, -26.0 in September and $72.6 \mathrm{~mm}$ in October. These values are generally lower than water needs of maize in other parts of the basin. Supplementary irrigation needs for groundnut cultivation for the months of May, June, July, August, September October were $77.9 \mathrm{~mm}, 31.1 \mathrm{~mm},-41.8 \mathrm{~mm},-101.8 \mathrm{~mm},-28.1 \mathrm{~mm}$ and $32.2 \mathrm{~mm}$ respectively. These values are lower in this part of the basin compared with water requirements for groundnut in the northwest, southwest and northeast parts of the basin. Tomato, cabbage and carrot require supplementary irrigation needs of $85.6 \mathrm{~mm}, 37.6 \mathrm{~mm},-35.9 \mathrm{~mm},-96.4 \mathrm{~mm},-22.9 \mathrm{~mm}$ and $75.9 \mathrm{~mm}$ for the months of May, June, July, August, September and October respectively. Monthly supplementary irrigation requirement in onion (dry) cultivation were estimated as $81.0 \mathrm{~mm}$ in May, $33.7 \mathrm{~mm}$ in June, $-39.4 \mathrm{~mm}$ in July, $-99.6 \mathrm{~mm}$ in August, $-26.0 \mathrm{~mm}$ in September and $72.6 \mathrm{~mm}$ in October.

Table 8a: Monthly supplementary irrigation water need for maize (grain) in mm, southeast, SokotoRima river basin

\begin{tabular}{|l|l|l|l|l|l|l|l|l|l|l|l|l|}
\hline & Jan & Feb & Mar & Apr & May & Jun & Jul & Aug & Sep & Oct & Nov & Dec \\
\hline $\mathrm{ET}_{\mathrm{o}, \mathrm{mm}}$ & 82.7 & 92.2 & 131.6 & 151.4 & 151.3 & 129.9 & 117.8 & 108.4 & 103.9 & 108.7 & 92.8 & 82.5 \\
\hline $\mathrm{K}_{\mathrm{c}}$ & 0.76 & 0.76 & 0.76 & 0.76 & 0.76 & 0.76 & 0.76 & 0.76 & 0.76 & 0.76 & 0.76 & 0.76 \\
\hline $\mathrm{ET}_{\text {crop }}$ & 62.8 & 70.1 & 100.0 & 115.1 & 115.0 & 98.7 & 89.6 & 82.4 & 78.9 & 82.6 & 70.6 & 62.7 \\
\hline $\mathrm{P}_{\mathrm{e}, \mathrm{mm}}$ & 0 & 0 & 0 & 3 & 34 & 65 & 129 & 182 & 105 & 10 & 0 & 0 \\
\hline $\mathrm{IR}, \mathrm{mm}$ & & & & & 81.0 & 33.7 & -39.5 & -99.6 & -26.0 & 72.6 & & \\
\hline
\end{tabular}

Source: Author's computation, (2017)

Table 8b: Monthly supplementary irrigation water need for groundnut in mm, southeast, SokotoRima river basin

\begin{tabular}{|l|l|l|l|l|l|l|l|l|l|l|l|l|}
\hline & Jan & Feb & Mar & Apr & May & Jun & Jul & Aug & Sep & Oct & Nov & Dec \\
\hline $\mathrm{ET}_{\mathrm{o}, \mathrm{mm}}$ & 82.7 & 92.2 & 131.6 & 151.4 & 151.3 & 129.9 & 117.8 & 108.4 & 103.9 & 108.7 & 92.8 & 82.5 \\
\hline $\mathrm{K}_{\mathrm{c}}$ & 0.74 & 0.74 & 0.74 & 0.74 & 0.74 & 0.74 & 0.74 & 0.74 & 0.74 & 0.74 & 0.74 & 0.74 \\
\hline $\mathrm{ET}_{\text {crop }}$ & 61.2 & 68.2 & 97.4 & 112.1 & 111.9 & 96.1 & 87.2 & 80.2 & 76.9 & 80.4 & 68.7 & 61.0 \\
\hline $\mathrm{P}_{\mathrm{e}, \mathrm{mm}}$ & 0 & 0 & 0 & 3 & 34 & 65 & 129 & 182 & 105 & 10 & 0 & 0 \\
\hline $\mathrm{IR}, \mathrm{mm}$ & & & & & 77.9 & 31.1 & -41.8 & -101.8 & -28.1 & 70.4 & & \\
\hline
\end{tabular}

Source: Author's computation, (2017)

Table 8c: Monthly supplementary irrigation water need for tomato/cabbage/carrot in mm, southeast, Sokoto-Rima river basin

\begin{tabular}{|l|l|l|l|l|l|l|l|l|l|l|l|l|}
\hline & Jan & Feb & Mar & Apr & May & Jun & Jul & Aug & Sep & Oct & Nov & Dec \\
\hline $\mathrm{ET}_{\mathrm{o}, \mathrm{mm}}$ & 82.7 & 92.2 & 131.6 & 151.4 & 151.3 & 129.9 & 117.8 & 108.4 & 103.9 & 108.7 & 92.8 & 82.5 \\
\hline $\mathrm{K}_{\mathrm{c}}$ & 0.79 & 0.79 & 0.79 & 0.79 & 0.79 & 0.79 & 0.79 & 0.79 & 0.79 & 0.79 & 0.79 & 0.79 \\
\hline $\mathrm{ET}_{\text {crop }}$ & 65.3 & 72.9 & 103.9 & 119.6 & 6 & 102.6 & 93.1 & 85.6 & 82.1 & 85.9 & 73.39 & 65.19 \\
\hline $\mathrm{P}_{\mathrm{e}, \mathrm{mm}}$ & 0 & 0 & 0 & 3 & 34 & 65 & 129 & 182 & 105 & 10 & 0 & 0 \\
\hline $\mathrm{IR}_{\mathrm{mm}}$ & & & & & 85.6 & 37.6 & -35.9 & -96.4 & -22.9 & 75.9 & & \\
\hline
\end{tabular}

Source: Author's computation, (2017)

Table 8d: Monthly supplementary irrigation water need for onion (dry) in mm, southeast, SokotoRima river basin

\begin{tabular}{|l|c|c|c|c|c|c|c|c|c|c|c|c|}
\hline & Jan & Feb & Mar & Apr & May & Jun & Jul & Aug & Sep & Oct & Nov & Dec \\
\hline $\mathrm{ET}_{\mathrm{o}, \mathrm{mm}}$ & 82.7 & 92.2 & 131.6 & 151.4 & 151.3 & 129.9 & 117.8 & 108.4 & 103.9 & 108.7 & 92.8 & 82.5 \\
\hline $\mathrm{K}_{\mathrm{c}}$ & 0.76 & 0.76 & 0.76 & 0.76 & 0.76 & 0.76 & 0.76 & 0.76 & 0.76 & 0.76 & 0.76 & 0.76 \\
\hline $\mathrm{ET}_{\text {crop }}$ & 62.8 & 70.1 & 100.0 & 115.1 & 115.0 & 98.7 & 89.6 & 82.4 & 78.9 & 82.6 & 70.5 & 62.7 \\
\hline $\mathrm{P}_{\mathrm{e}, \mathrm{mm}}$ & 0 & 0 & 0 & 3 & 34 & 65 & 129 & 182 & 105 & 10 & 0 & 0 \\
\hline
\end{tabular}




\begin{tabular}{|l|l|l|l|l|l|l|l|l|l|l|l|}
\hline IR, $\mathrm{mm}$ & & & & & 81.0 & 33.7 & -39.4 & -99.6 & -26.0 & 72.6 & \\
\hline
\end{tabular}

Source: Author's computation, (2017)

\subsection{Conclusion}

The first three decades 1940, 1950 and 1960 were the wet decades in the Sokoto-Rima River Basin. This rising trend was interrupted by a break in 1970. There was a continuous downward trend in annual rainfall distribution from 1970 with a sign of weak rising trend around 2000. Temperature on the other hand showed evident of rising trends for all the sections of the basin from 1970 into 2010. Between 1940-1960 mean temperatures clustered below mean line. These correspond to periods of drought in the arid and semi-arid Nigeria. For example using the Standard Precipitation Index (SPI), Abubakar and Yamuda (2013) showed that drought occurrence was first noticed in this zone in 1968 with a Standardized Precipitation Index value of $(-0.34)$, indicative of a mild drought. These negative SPI values of drought episodes continued up to 1973, with the exception of 1970. From 1981-1997, the zone again witnessed the longest drought episodes, which lasted for nearly a decade and half. This period was characterized by absolute dryness except. However, there were moments of respite in the later years (1996-2004) during which drought episodes were fast recovering from dryness to wetness. Cause of drought in this zone during the 1970s, 1980s and 1990s has been linked to the prevalence of a stagnated anti-cyclonic circulation of the tropical atmosphere over areas that normally should be exposed to the rising arm of the tropical Hadley Cell circulation by mid-summer (Kalu, 1987; Adefolalu, 1986; Kamara, 1986). These conditions are themselves related to the tropical component of the global general circulation system. This study present evidence of changing climate and variability and since the basin houses big irrigation projects and dams such as the Goronyo Irrigation and the Bakolori Dam and Bakolori Irrigation Project, north of the basin, we must be concerned regarding the impact of this observation on the water availability within the basin for ongoing irrigation and other water resources projects as a result of rapid moisture loss by evaporation and evapotranspiration. Results of supplementary irrigation showed that water of different quantity is required in the months of onset and cessation of rains. This has a lot of implications for early crop plantation. A temporal water deficit is fatal to crop development especially during the vegetative and flowering stages of the crops. Finding from the study also showed that an all-year- round planting can be carried out adopting the supplementary irrigation schedule provided in the study.

\section{References}

Abaje, I. B., Ati, O. F. and Iguisi, E.O. (2011). Drought in the North-Eastern part of Nigeria and the risks on human health, in E. O. Iguisi, O. A. Ati, R. O. Yusuf and A. E. Ubogu (eds) NMets Zaria 2011 Proceedings of the International Conference of the Nigerian Meteorological Society, pp. 527538.

Abdul-Rahaman, I., Campion, B. B. and Edziyie, R. (2016). Rainfall and temperature changes and variability in the Upper East Region of Ghana. Earth and Space Science, 3, doi:10.1002/ 2016EA000161.

AbdulKadir, A., Usman, M. A. and Shaba, A. H. (2013). Climate change, aridity trend and agricultural sustainability of the Sudano-Sahelian belt of Nigeria. International Journal of Development and Sustainability, 2(2), pp. 1436-1456.

Abubakar, L. U. and Yamuda, M. A. (2013). Recurrence of drought in Nigeria. Cause, Effects and Mitigation. International Journal of Agriculture and Food Science Technology, 4(3), pp. 169-180.

Adefolalu, D. O. (2007). Climate change and economic sustainability in Nigeria. Paper presented at the International Conference on Climate Change and Economic Sustainability held at Nnamdi Azikiwe University, Enugu, Nigeria, 12-14 June 2007

Adefolalu, D. O. (1986). Rainfall trends in Nigeria. Theoretical and Applied Climatology, 37, pp. 205-219.

Adejuwon, J. O. (2006a). Food crop production in Nigeria II: Potential effects of climate change. Clim Res, 32, pp. 229-245. 
Adejuwon, J. O. (2006b). Food security, climate change variability and climate change in subSaharan West Africa. Assessment of Impacts and Adaptations to Climate Change (AIACC). AIACC Project Office, Washington DC.

Adelana, S. M. A., Olasehinde, P. I. and Vrbka, P. (2003). Isotope and geochemical characterization of surface and subsurface waters in the semi-arid Sokoto Basin, Nigeria. African Journal of Science and Technology, 4(2), pp. 76-89.

Allen, R. G., Smith, M., Perrier, A., and Pereira, L. S. (1994). An update for the definition of reference evapotranspiration. ICID Bulletin, 43(2), pp. 1-34.

Allen, R. G., Pereira, L. S., Raes, D. and Smith, M. (1998). Crop evapotranspiration - Guidelines for computing crop water requirements. FAO Irrigation and Drainage, Paper No. 56, FAO, Rome.

Anyadike, R. N. C. (1987). The Linacre evaporation formula tested and compared to others in various climates over West-Africa. Agricultural and Forest Meteology, 39, pp. 111-119.

Aondoakaa, S. C. (2012). Effects of Climate Change on Agricultural Productivity in the Federal Capital Territory (FCT), Abuja, Nigeria. Ethiopian Journal of Environmental Studies and Management EJESM, 5(4), pp. 559-566.

Audu, E. B. I., Audu, H. O., Binbol, N. L. and Gana, J. N. (2013). Climate Change and Its Implication on Agriculture in Nigeria. Abuja Journal of Geography and Development, 3(2), pp. 8-19.

Ayoade, J. O. (1983). Introduction to Climatology for the Tropics. Spectrum Books Ltd, Ibadan.

Ayuba, K. H. and Dami, A. (2011). Environmental Science. An Introductory Text. Published by Apani publications, pp. $44,73 \& 75$.

Bello, N. J. (2010). Climate Change: Implications for food production and security in Nigeria. In: Climate Change Impacts and Adaptation: Developmental Issues. A Special Book on Climate Change. Published by Nigerian Meteorological Society, pp. $3 \& 5$

Dingman, S. L. (2002). Physical Hydrology, 2nd edition, Prentice-Hall, Upper Saddle River, 646 pp.

Ekpoh, I. J. (1999). Rainfall and Peasant Agriculture in Northern Nigeria. Global Journal of Pure and Applied Sciences, 5(1), pp. 123-128.

FAO (2002). Crop Water Requirements and Irrigation Scheduling. In: A. P. Savva and K. Frenken (eds.) FAO Irrigation Manual Module 4 Rome, Italy.

FAO (2018). Northeastern Nigeria Adamawa, Borno and Yobe States Results of the 2017 rainy season programme. Food and Agriculture Organization of the United Nations Rome, 2018.

Food and Agriculture Organization of the United Nations FAO (1986). Irrigation Management, Training Manual, No 3. Via delle Terme di Caracalla, 00100 Rome, Italy.

Hamon, W. R. (1961). Estimating potential evapotranspiration. Journal of the Hydraulics, 87, pp. $107-120$.

Hanafi, A. and Jauffret, S. A. (2008). Long-term vegetation dynamics useful in monitoring and assessing desertification processes in the arid steppe, southern Tunisia. Journal of Arid Environments, 72(4), pp. 557-572.

Huang, S. and Siegert, F. (2006). Land cover classification optimized to detect areas at risk of desertification in North China based on Spot Vegetation imager. Journal of Arid Environments, 67(2), pp. $308-327$. 
IPCC (2007). Climate Change 2007: Synthesis Report. Contribution of Working Group I, II and III to the Fourth Assessment Report of the Intergovernmental Panel on Climate Change.

Ita, E. O. (1993). Inland Fishery Resources of Nigeria CIFA Occasional Paper No 20. Rome, FAO. 1993. $120 \mathrm{pp}$.

Jagtap, S. (2007). Managing vulnerability to extreme weather and climate events: Implications for agriculture and food security in Africa. In: Proceedings of the International Conference on Climate Change and Economic Sustainability held at Nnamdi Azikiwe University, Enugu, Nigeria, 12-14 June 2007.

Junliang, J., Guoqing, W., Jianyun, Z., Qinli, Y., Cuishan, L., Yanli, L., et al. (2016). Impacts of climate change on hydrology in the Yellow River source region, China. Journal of Water and Climate Change, jwc2018085 https://doi.org/10.2166/wcc.2018.085

Kalu, A. E. (1987). The recurrence of severe droughts in northern Nigeria. In: Proceedings of the 1985 Commonwealth Meteorologists Conference, Meteorological Office College, Reading.

Kamara, S. I. (1986). The origin and types of rainfall in West Africa. Weather, 41, pp. 48-56.

Kim Chang-gil. (2009). Strategies for Implementing Green Growth in Agricultural Sector. In: Proceedings in Green Korea 2009 - Green Growth and Cooperation. National Research Council for Economics, Humanities and Social Science.

Ma, Z., Kang, S., Zhang, L., Tong, L. and Su, X. (2008). Analysis of impacts of climate variability and human activity on streamflow for a river basin in arid region of northwest China. Journal of Hydrology, 352, pp. 239-249.

McCabe, G. J., and Markstrom, S. L. (2007). A monthly water-balance model driven by a graphical user interface. U.S. Geological Survey Open-File report 2007-1088, 6 pp.

Mitchell, T. D. and Jones, P. D. (2005). An Improved method of constructing a database of monthly climate observations and associated high-resolution grids. Int. J. Climatol. 25, pp. 693-712.

Mortimore, M. J. and Adams, W. M. (2001). Farmer adaptation, change and crises in the Sahel. Global Environmental Change-Human and Policy Dimensions, 11, pp. 49-57.

Mu, X., Zhang, L., McVicar, T. R., Chille, B. and Gau, P. (2007). Analysis of the impact of conservation measures on stream flow regime in catchments of the Loess Plateau, China. Hydrological Processes, 21, pp. 2124-2134.

National Emergency Management Agency (NEMA) (2010). Post Disaster Assessment for Nigeria.

New, M., Hulme, M. and Jones, P. D. (2000). Representing twentieth century space-time climate variability. Part 2: Development of 1901-96 monthly grids of terrestrial surface climate. J. Climate, 13, pp. 2217-2238.

NPC (2006). 2006 Population and Housing Census. Priority Table Volume III Population Distribution by Sex, State, LGA \& Senatorial District National Population Commission Abuja, Nigeria April, 2010.

Nwafor, J. C. (2007). Global climate change: The driver of multiple causes of flood intensity in SubSaharan Africa. Paper presented at the International Conference on Climate Change and Economic Sustainability held at Nnamdi Azikiwe University, Enugu, Nigeria, 12-14 June 2007.

Obi, C. O. (2010). Climate Change and Management of Degraded Soils for Sustainable Crop of Production. Tropical Built Environment Journal. 1(1), pp. 33, 36 \& 37. 
Odjugo, P. A. O. (2001). Global warming and food production: A global and regional analysis. Afr J Environ Stud. 2(2), pp. 85-91.

Oguntunde, P. G., Abiodun, B. J. and Lischeid, G. (2011). Rainfall trends in Nigeria, 1901-2000. J. Hydrol., 411, pp. 207-218.

Penman, H. L. (1948). Natural evaporation from open water, bare soil, and grass. Proceedings of the Royal Society of London, A193 (1032), pp. 120-146.

Qin, D.Y., Lü, J.Y., Liu, J. H. and Wang, M. N. (2009). Theories and calculation methods for regional objective ET. Chinese Science Bulletin, 54(1), pp. 150-157.

Singh, S. K, Singh, K. M., Singh R. K. P., Kumar, A. and Kumar, U. (2014). Impact of Rainfall on Agricultural Production in Bihar: A Zone-Wise Analysis. Environment and Ecology, 32 (4A), pp. 1571-1576.

Sivakumar, M. V. K. (2007). Interactions between climate and desertification. Agricultural and Forest Meteorology, 142. 2-4, pp. 143-155.

Sombroek, W. G. and Zonneveld, I. S. (1971). Ancient Dunes Fields and Fluviatile Deposits in the Rima Sokoto River Basin, Soil Survey. Paper No. 5, Netherland Soil Survey Institute, Wageningen, $109 \mathrm{pp}$.

Sonia, K., Max, R., Minus, V. B. and Michel, L. (2007). Local facilitation, bistability and transitions in arid ecosystems. Theoretical Population Biology, 71(3), pp. 367-379.

Susana, B. A. and Kelley, A. C. (2006). Aridity and desertification: Exploring environmental hazards in Jáchal, Argentina. Applied Geography, 26(1), pp. $61-85$.

Thompson, O. A. and Amos, T. T. (2010). Climate Change and Food Security in Nigeria. Journal of Meteorology and Climate Science. 8(2). pp. 92-95.

Zhang, S. and Lu, X. X. (2009). Hydrological responses to precipitation variation and diverse human activities in a mountainous tributary of the lower Xijiang, China. CATENA, 77, pp. 130-142.

Zhao, H. L., Zhao, X. Y., Zhou, R. L., Zhang, T. H. and Drake, S. (2005). Desertification processes due to heavy grazing in sandy rangeland, Inner Mongolia. Journal of Arid Environments, 62(2), pp. 309-319. 